Research Article

\title{
Predicting COVID-19 impact on demand and supply of cryptocurrency using machine learning
}

\author{
David Opeoluwa Oyewola $^{a, *}$ (D), Emmanuel Gbenga Dada ${ }^{b}$ (D), Ndunagu Juliana Ngozi ${ }^{c}$ (D), \\ Daniel Eneojo Emmanuel ${ }^{a}$
}

${ }^{a}$ Department of Mathematics \& Computer Science, Federal University Kashere, Gombe, Nigeria

${ }^{b}$ Department of Mathematical Sciences, Faculty of Science, University of Maiduguri, Maiduguri, Nigeria.

${ }^{c}$ Department of Computer Sciences, National Open University of Nigeria, Nigeria.

\begin{tabular}{|c|c|}
\hline ARTICLE INFO & ABSTRACT \\
\hline $\begin{array}{l}\text { Article history: } \\
\text { Received } 27 \text { June } 2021 \\
\text { Accepted } 13 \text { September } 2021 \\
\text { Keywords: } \\
\text { Bitcoin } \\
\text { Cryptocurrency } \\
\text { Support Vector Machine }\end{array}$ & $\begin{array}{l}\text { In the wake of recent pandemic of COVID-19, we explore its unprecedented impact on the demand } \\
\text { and supply of cryptocurrencies'market using machine learning such as Naïve Bayes (NB), } \\
\text { Decision Trees (C5), Decision Trees Bagging (BG), Support Vector Machine (SVM), Random } \\
\text { Forest (RF), Multinomial Logistic Regression (MLR), Recurrent Neural Network (RNN), Long } \\
\text { Short Term Memory and Noise Bagging (NBG). The study employed Noise filters to enhance the } \\
\text { performance of Decision Trees Bagging named NBG. Dataset utilized for this analysis were } \\
\text { obtained from the website of Coin Market Cap, including: Binance Coin (BCN), BitCoin Cash } \\
\text { (BCH), BitCoin (BTC), BitCoinSV (BSV), Cardano (CDO), Chainlink (CLK), CryptoCoin } \\
\text { (CCN), EOS (EOS), Ethereum (ETH), LiteCoin (LTC), Monero (MNO), Stellar (SLR), Tether } \\
\text { (TTR), Tezos (TZS), XRP (XRP), and daily data collected from exchange markets platforms spans } \\
\text { from 2nd January 2018 to 7th July 2020. Auto encoder was utilized for the labelling of the trading } \\
\text { strategies buy-hold-sell. }\end{array}$ \\
\hline
\end{tabular}

This is an open access article under the CC BY-SA 4.0 license. (https://creativecommons.org/licenses/by-sa/4.0/)

\section{Introduction}

Cryptocurrency is a digital currency in which transactions are validated and records are kept by a decentralized system rather than a centralized authority utilizing encryption. Cryptocurrencies have reached the pinnacle of prominence in the global financial markets. This type of currency exists exclusively as a means of trade in the digital realm. The most well-known cryptocurrency is Bitcoin, which is available on the internet. As of January 2021, there are over 4,000 cryptocurrencies in circulation [1]. The top 5 cryptocurrencies include Bitcoin, Ethereum, XRP, Tether and Bitcoin Cash, depending on their market capitalization [2]. Bitcoin has grown incredibly famous throughout the years as a first ever crypto-currency type proclaimed in 2009 because of its unique features. It is not only the first type of a decentralized peer-to-peer network, but is also exclusively managed by Bitcoin users worldwide. Bitcoin allows its users to be in complete control while ensuring identity protection without having any central authority to oversee transactions. More specifically, there's no link beyond the possession of a Bitcoin owner, suggesting that the identity of anyone engaged in a Bitcoin transaction is practically anonymous [3]. The Novel Coronavirus, sometimes called COVID-19, was one of the newest economic concerns; China officially recognized the pneumonia virus in 2019. Wuhan, China, the source of coronavirus was quarantined by 23 January 2020 as the virus spreads wildly over several nations and continents [4]. With COVID-19 rapidly spreading throughout the country, it became a national issue causing to massive industrial and corporate shutdowns. Given that the worldwide Chinese trade share is as high as 14 percent [4], its influence on financial markets globally is far greater than any previous economic uncertainty. 
Cryptocurrencies (including Bitcoin (BTC), ETH and Ripple (XRP)) were studied for the connection of cases and fatalities between COVID-19 by [5]. The results suggest that the study of the wavelet consistency demonstrates a negative link between the Bitcoin case and the number of reported deaths. The findings are comparable, but with weakest connections for Ethereum and Ripple. This promotes the role of cryptocurrencies in protecting against the uncertainty that COVID-19 raises. Cryptocurrency markets are complicated speculative systems. The herding distortions were explored in a research [6] by measuring the intensity of cryptocurrency returns' self-similarity during the COVID-19 epidemic. In multifractal investigation before and after the coronavirus epidemic, the researchers examined the level of effectiveness of cryptocurrencies. The results demonstrate that COVID-19 has a favorable effect on the effectiveness of the bitcoin market. Following the recent COVID-19 epidemic [7], the researcher explores the unprecedented consequences on the market for cryptocurrencies. They investigate how the change of COVID-19 intensity indicated by the daily increase in new global infections impacts the daily returns according to market capitalization of the top 10 cryptocurrencies. The results of the Quantile-on-Quantile Regression (QQR) approach indicate that the changing intensity of the COVID-19 influence cryptocurrencies differently in the Bearish and Bullish market. The findings of this new asset class indicate novel, asymmetrical dynamics versus a very stressful and unexpected occurrence of COVID-19. In the pre-pandemic and post-pandemic of COVID-19, the authors [8] analyze the relationship among the leading cryptocurrencies on crypto markets utilizing nine cryptocurrencies such as Bitcoin, Ethereum, Ripple, Litecoin, Eos, BitcoinCash, Binance, Stellar and so on. Findings demonstrate that Bitcoin and altcoins have significant evidence of long-lasting relationships regardless of whether they are in pre-pandemic or pandemic times. They also noticed that the pricing and interrelationship of cryptocurrencies are robust to the pandemic. The idea was that investors should consider Bitcoin and Altcoins together when creating investment plans and strategies, because they provide sustainability and resistance against geopolitical risks and even in the difficult times of the 19-COVID epidemic. The predictable nature of three main cryptocurrencies (Bitcoin, Etheum and Litecoin) and of trade methods based on machine learning techniques such as linear models, random forests, and support vector machines is explored in a study by [9]. They utilized assembling of models in their trading strategies comprises of five models, the best performance was achieved from etherium and litecoin. Also, the annualised Sharpe ratios are $80.17 \%$ and $91.35 \%$, and annualized returns are $9.62 \%$ and $5.73 \%$. The authors [10] employed machine learning and Artificial Intelligence
(AI)-assisted trading in their research. They assess the cryptocurrency market's effectiveness on the basis of dayto-day data on 1,681 coins between November 2015 and April 2018. Their findings indicated that basic trading techniques, supported by state-of-the-art machine learning algorithms, exceed standard benchmarks. A model was developed for active trading based on reinforcement machine learning [11]. They utilized reinforcement machinery learning with the help of buy-and-hold strategy to five main cryptocurrencies. They show how this approach provides increased risk-adjusted returns and reduces downside risks. The authors [12] employed machine learning in stock market prediction using machine learning, deep learning, stochastic process and proposed Auditory algorithms such as Logistic Regression (LR), Support Vector Machine (SVM), Feed forward neural network (FFN), Recurrent Neural Network (RNN), Stochastic Differential Equation (SDE) and Geometric Brownian Motion (GBM). The performance of Auditory Algorithm (AA) is compared with that of high performing machine learning, deep learning algorithms and continuous-time stochastic process. The results show that the overall performance of AA is superior to that of other algorithms compared in the paper. Table I displays the summary of related work on cryptcurrency.

Our contributions to this work are outlined below:

The impact of COVID-19 on Demand and Supply of cryptocurrency prediction and analysis of Binance Coin (BCN), BitCoin Cash (BCH), BitCoin (BTC), BitCoinSV (BSV), Cardano (CDO), Chainlink (CLK), CryptoCoin $(\mathrm{CCN})$, EOS (EOS), Ethereum (ETH), LiteCoin (LTC), Monero (MNO), Stellar (SLR), Tether (TTR), Tezos (TZS), XRP (XRP) and others was presented in this paper.

Performance comparison of these cryptocurrencies using Machine learning such as Naïve Bayes (NB), Decision Trees (C5), Decision Trees Bagging (BG), Support Vector Machine (SVM), Random Forest (RF), Multinomial Logistic Regression (MLR), Recurrent Neural Network (RNN), Long Short Term Memory and Noise Bagging (NBG) respectively was analyzed.

The effectiveness of the machine learning model was analysis using different performance metrics such as Sensitivity, Specificity and Accuracy.

\section{Materials and Methods}

\subsection{Description of Cryptocurrency Dataset}

Dataset utilized for this analysis were obtained from the website of Coin Market Cap, including: Binance Coin (BCN), BitCoin Cash (BCH), BitCoin (BTC), BitCoinSV (BSV), Cardano (CDO), Chainlink (CLK), CryptoCoin (CCN), EOS (EOS), Ethereum (ETH), LiteCoin (LTC), Monero (MNO), Stellar (SLR), Tether (TTR), Tezos (TZS), XRP (XRP), and daily data collected from 
exchange markets platforms spans from 2nd January 2018 to 7 th July 2020 as shown in Fig. 1. Cryptocurrency data obtained from the website contains the daily closing price, open price, high price, low price, volume and change percentage in US dollars. The data sets for the exchange market are split into two sets, training and testing dataset. The training dataset spans from January 2018 to December 2019 of the daily data of exchange market cryptocurrency and the remaining of the daily data from January 2020 to July 2020 were utilized for the testing dataset as shown in Fig. 2. The period of testing dataset was selected due to the impact of COVID-19 in the world economy, which has become a global pandemic [13-14]

Table 1. Summary of related work on Cryptocurrency

\begin{tabular}{|c|c|c|}
\hline Reference & Methods & Results \\
\hline $\begin{array}{c}\text { Thomas et al } \\
{[11]}\end{array}$ & $\begin{array}{l}\text { Direct Reinforcement } \\
\text { Learning }\end{array}$ & $\begin{array}{c}\text { Portfolio Metrics: } \\
\text { Cummulative } \\
\text { Returns (DR) }= \\
3.39 \%\end{array}$ \\
\hline $\begin{array}{c}\text { Laura et al. } \\
{[10]}\end{array}$ & $\begin{array}{c}\text { Gradient Boosting, } \\
\text { Decision Trees, Long } \\
\text { Short Memory, Recurrent } \\
\text { Neural Network }\end{array}$ & $\begin{array}{l}\text { Geometric mean } \\
\text { return: } 98.5,98.8 \%\end{array}$ \\
\hline $\begin{array}{l}\text { Helder et al. } \\
\text { [9] }\end{array}$ & $\begin{array}{c}\text { Linear Models, Random } \\
\text { Forest, Support Vector } \\
\text { Machine }\end{array}$ & $\begin{array}{c}\text { Sharpe Ratio: } \\
80.17 \% \\
\text { Annualized Return: } \\
91.35 \%\end{array}$ \\
\hline $\begin{array}{c}\text { Erdinc et al. } \\
{[24]}\end{array}$ & $\begin{array}{l}\text { k-Nearest Neighbours, } \\
\text { Logistic Regression, } \\
\text { Naive Bayes, Random } \\
\text { Forest, Support Vector } \\
\text { Machine, Extreme } \\
\text { Gradient Boosting }\end{array}$ & $\begin{array}{c}\text { Logistic Regression: } \\
\text { 54\% } \\
\text { Naïve Bayes: 45\%, } \\
\text { Extreme Gradient } \\
\text { Boosting: } 55 \% \\
\text { Support Vector } \\
\text { Machine: } 71 \% \\
\text { k-Nearest } \\
\text { Neighbour: } 87 \% \\
\text { Random Forest: } \\
83 \%\end{array}$ \\
\hline $\begin{array}{l}\text { Muhammed et } \\
\text { al. [25] }\end{array}$ & $\begin{array}{c}\text { Artificial Neural Network } \\
\text { (ANN), Stacked Artificial } \\
\text { Neural Network (SANN), } \\
\text { Support Vector Machine } \\
\text { (SVM), Long Short Term } \\
\text { Memory (LSTM) }\end{array}$ & $\begin{array}{l}\text { ANN: } 57 \% \\
\text { SANN: } 62 \% \\
\text { SVM: } 65 \% \\
\text { LSTM: } 54 \%\end{array}$ \\
\hline
\end{tabular}

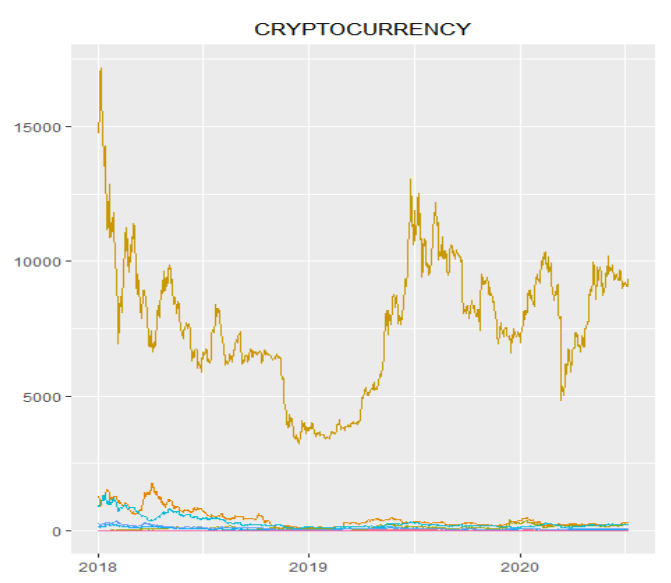

Figure 1. Cryptocurrency dataset (x-axis represents the year and $y$-axis is the Closing price of the cryptocurrency)

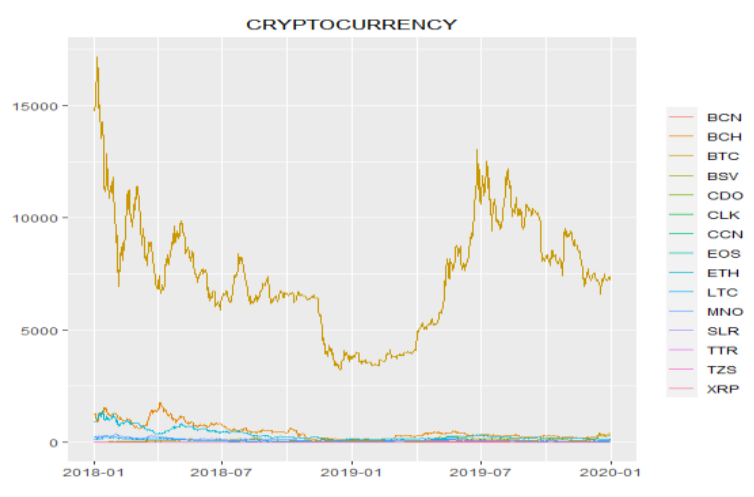

Figure 2. Training dataset of $\mathrm{BCN}, \mathrm{BCH}, \mathrm{BTC}, \mathrm{BSV}, \mathrm{CDO}$, CLK, CCN, EOS, ETH, LTC, MNO, SLR, TTR, TZS, XRP (xaxis represents the year and $y$-axis is the Closing price of the cryptocurrency)

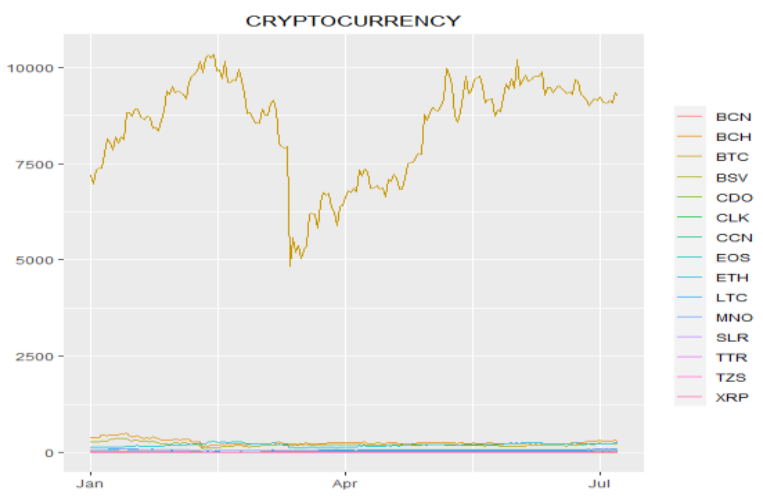

Figure 3. Testing dataset of $\mathrm{BCN}, \mathrm{BCH}, \mathrm{BTC}, \mathrm{BSV}, \mathrm{CDO}$, CLK, CCN, EOS, ETH, LTC, MNO, SLR, TTR, TZS, XRP (xaxis represents the year and $y$-axis is the Closing price of the cryptocurrency).

\subsection{Technical Indicators}

In order to monitor the development of cryptocurrency prices as well as to develop trading rules to buy-sell-hold decisions, researchers and investors have used a wide range of technical indicators. Throughout this analysis, five famous technical indicators such as Simple Moving Average (SMA), Chande Momentum Oscillator (CMO), Detrended Price Oscillator (DPO), Exponential Moving Average (EMA) and Weighted Moving Average (WMA) are chosen as input to the model. The technical indicators are determined from historical prices as follows:

Simple Moving Average (SMA)

SMA can be expressed as:

$S_{m}=\frac{1}{t} \sum_{i=1}^{t} C_{t}$

\section{Chande Momentum Oscillator (CMO)}

CMO can be expressed as:

$C_{m}=\frac{H\left(\sum_{i=1}^{t} C_{t}\right)-L\left(\sum_{i=1}^{t} C_{t}\right)}{H\left(\sum_{i=1}^{t} C_{t}\right)+L\left(\sum_{i=1}^{t} C_{t}\right)}$

Detrended Price Oscillation (DPO) 
DPO can be expressed as:

$\mathrm{D}_{\mathrm{p}}=\mathrm{C}_{\mathrm{t}}-\left(\operatorname{SMA}\left(\frac{\mathrm{t}}{2}+1\right)\right)$

\section{Exponential Moving Average (EMA)}

Exponential moving average of $n$ days is calculate as:

$E_{m}=C_{t} \times \propto+E_{(m-1)} \times(1-\propto)$

$\propto=2 \div(n+1)$

Weighted Moving Average (WMA)

$\mathrm{W}_{\mathrm{m}}=\sum_{\mathrm{i}=1}^{\mathrm{t}} \frac{\mathrm{t} \times \mathrm{C}_{\mathrm{i}}-(\mathrm{t}-1) \mathrm{C}_{\mathrm{i}} \ldots \mathrm{C}_{\mathrm{t}}}{\frac{\mathrm{t}(\mathrm{t}+1)}{2}}$

Where $C_{t}$ is the closing price at time $t, H$ is the highest price, $L$ is the lowest price,

$E_{m}$ is the exponential moving average at time $t, \propto$ is the exponential smoothing factor.

\subsection{Machine Learning framework for cryptocurrency prediction}

\section{Naïve Bayes (NB)}

The classification method Naïve Bayes is based on the Bayes theorem. Bayes theorem offers a method to estimate posterior probability, $P(c \mid x)$, from class prior probability $P(c)$, predictor prior probability $P(x)$, and likelihood $P(x \mid c)$. The classifier of Naive Bayes presumes that the predictor value $(x)$ on a given class $(c)$ is independent of other predictors values. This presumption is referred to as a class conditional independence. The Bayes principle [15] is based on Bayes formula as follows:

$P(c \mid x)=\frac{P(X \mid C) P(c)}{P(x)}$

Where $P(c \mid x)$ is the posterior probability of the buysell-hold target class given $S_{m}, C_{m}, D_{p}, E_{m}, W_{m}$ predictor, $P(c)$ is the prior probability of class, $P(x \mid c)$ is the likelihood which is the probability of $S_{m}, C_{m}, D_{p}, E_{m}, W_{m}$ predictor given class and $P(x)$ is the prior probability of $S_{m}, C_{m}, D_{p}, E_{m}, W_{m}$ predictor.

\section{Decision Trees $(\mathbf{C 5})$}

The algorithm $\mathrm{C} 5.0$ is $\mathrm{C} 4.5$ extensions. The performance and memory of C5.0 is higher than C4.5. C5.0 model works by dividing the sample into a field which provides the highest gain of information. On the basis of the most significant knowledge gains region, the C5.0 model will separate samples. The sample subset obtained from the previous division is subsequently divided. The cycle continues until a subset of the sample cannot be divided and normally depends on another field. Lastly, the lowest division is examined, which will be rejected for those subset that do not contribute considerably to the model [16].

\section{Decision Tree Bagging (BG)}

Decision Tree Bagging $(B G)$ is a general approach by which many variations of predictive model are modified to merge them into an aggregated prediction [17]. Bagging is a very direct algorithm in which the original training data is generated using bootstrap copy $b$. The base learners' predictions are combined in a classification problem with the majority voting or by combining the measured class probabilities. The equations for bagging are as follows:

$b_{g}=f_{1}(X)+f_{2}(X)+\cdots+f_{n}(X)$

where $X$ is the record for which we want to generate a prediction, $b_{g}$ is the bagged prediction, and $f_{1}(X)$, $f_{2}(X), f_{n}(X)$ are the predictions from the individual base learners.

\section{Proposed Method}

In cryptocurrency it is very important to be able to predict buy-sell-hold trading decision signal accurately. When traders are aware of the best time to buy-sell-hold assets on the cryptocurrency market, many traders will benefit more. It is worth observing the price movements of virtual coins, as well as the exchange in physical goods and products. In a nutshell, market timing is a buying-sellingholding trading strategy will be built upon the concept of beating the market by predicting it using proposed method. In this section, in order to beat the exchange market cryptocurrency, we employ auto-encoder.

\section{Auto Encoder}

Autoencoder is unsupervised learning that comprises three layers: a hidden layer, output layer, input layer as shown in Fig. 4. Two important elements which are encoder and decoder components are involved in an autoencoder. An encoder maps the input layer to the hidden layer, while the decoder map returns this hidden layer to the original input layer. The input dataset $\left\{x_{n}\right\}$ is all the cryptocurrency dataset used in this research.

The encoding and decoding process is as follows:

$h_{n}=\sigma\left(W_{1} x_{n}+b_{1}\right)$

$\hat{x}_{n}=\rho\left(W_{2} h_{n}+b_{2}\right)$

where $\sigma$ is the encoding function, $\rho$ is the decoding function, $W_{1}$ is the weight matrix of the encoder, $W_{2}$ is the weight matrix of the decoder, $b_{1}$ is the bias vector of the encoder, $b_{2}$ is the bias vector of the decoder. 


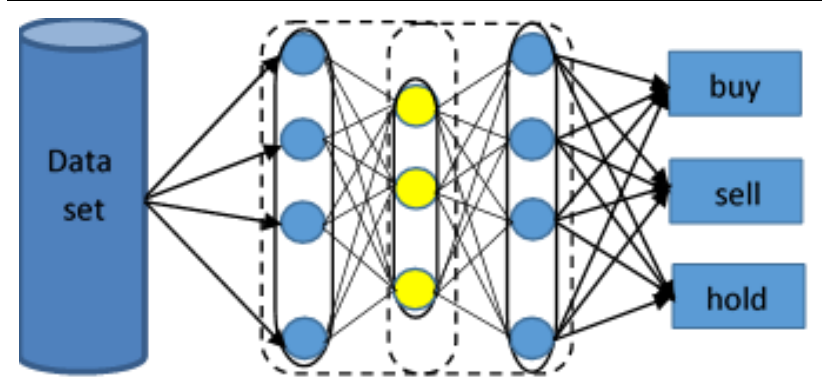

Figure 4: Structure of buy-sell-hold strategy using Autoencoder

\section{Trading strategy of buy-sell-hold decisions}

The output obtained from the decoder, is then processed using straight forward rules as follows:

If (action is greater than 1) then decision is "buy"

If (action is between 1 and 0.5 ) then decision is "sell"

If (action is less than 0.5 ) then decision is "hold"

\section{Enhancement of Noise Filter Bagging (NBG)}

The efficiency of the classifiers designed under such circumstances which we generally want to optimize will depend heavily on the quality of the training data but also on the ruggedness of the classifier against noise. So training or test data with noise are complex problems and often difficult to achieve accurate solutions [18-22].

Noise in data can influence the intrinsic characteristics of a classification problem, as this can lead to new properties being introduced into the problem region. The dataset collected from the real-world are never flawless and often distorted that may inhibit the system efficiency. Therefore, data gathered from real-world problems are never perfect and often suffer from corruptions that may hinder the performance of the system. In order to have a clean data from the classes of buy, sell and hold strategy, we employed the approach of Tomek [23]. The mathematics equation is given as:

$C_{d}=\aleph\left(\widehat{x_{b s h}}, r\right)$

Where $C_{d}$ is the clean data, $\boldsymbol{N}$ is the noise filters algorithm, $\widehat{x_{b s h}}$ is the decision output buy-sell-hold, $r$ is the technical indicators $\left(S_{m}, C_{m}, D_{p}, E_{m}, W_{m}\right)$.

The main steps taken to predict cryptocurrency by enhanced decision tree bagging (BG) are listed below:

Firstly, cryptocurrency datasets containing fifteen major currencies was used for our experiments.

Secondly, preprocessing operations to transform the data to buy-sell-hold decisions was carried out prior to training the machine learning model.

Thirdly, preprocessing operation obtained is used as target class while the technical indicator is used as the predictor on all the three machine learning. To improve the accuracy of BG, next stage is employ.
Lastly, noise filter was carried out on the training dataset and the selected test dataset obtained from the clean data was applied to decision tree bagging (BG) which will enable us to improve the accuracy of the BG.

\section{Results}

Table II presents the statistical summary of the entire cryptocurrency utilized in this study. The minimum, first quartile, median, mean, third quartile, maximum and standard deviation. The highest closing price is obtained from BitCoin (BTC) while the lowest price is CryptoCoin $(\mathrm{CCN})$. The prices of Tether (TTR), Cardano (CDO), CrptoCoin (CCN), Stellar (SLR) and XRP have shown lower volatility which indicated that the coin prices tend to be more stable. The reward can be high for trader investing in BitCoin (BTC) and BitCoin Cash (BCH) coin, but the risk associated with high volatility must be taken into account.

Biplot is a useful visualization tool for assessing the performance of cryptocurrency data. All the fifteen cryptocurrencies utilized in this study are present in the same plot. As shown in Fig. 5 most of the cryptocurrency data tends cluster together. BCN, BSV, BTC, CDO, CLK, ETH, MNO, TZS and XRP are positive correlated while there is no correlation between TTR and SLR.

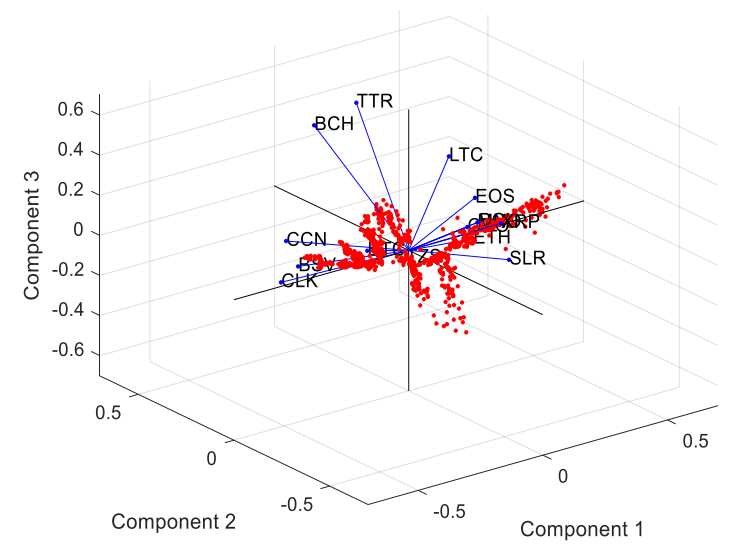

Figure 5. Biplot of Cryptocurrency

The investor who take advantage of the buy-sell-hold strategy will be able to predict when to buy, to sell and to hold. Table III display all the fifteen cryptocurrency strategy of the buy-sell-hold decisions. The exchange market of cryptocurrency works on the concepts of supply and demand, buyers tends to bid more of ETH, BTC, BSC, this result in the increase price of cryptocurrency while CDO, CCN, SLR, TTR and TZS have no supply, this cause the price of the cryptocurrency to fall. $\mathrm{CDO}, \mathrm{BCH}, \mathrm{XRP}$, TTR tends to have more sellers while BTC, ETH, BCN have low sellers. Most traders tend to hold more of TZS, CLK and SLR. Table IV shows impact of demand and supply of cryptocurrency on COVID-19. The results show that traders hold more of cryptocurrency during COVID- 
19 which shows that demand and supply of cryptocurrency was very low.

It is of paramount importance to address the strength and accuracy of the proposed method. We have carried out noise filters technique on decision tree bagging (BG) named NBG in this paper. Noise filters removes noise from the training data and improve the accuracy of the test data set of NBG as shown in Table V-VI. The performance of NB, C5, BG, NBG, SVM, RF, MLR, RNN and LSTM classification model is evaluated using Sensitivity, Specificity, Positive Predicted Value (PPV), Negative Predicted Value (NPV), Balanced Accuracy, Overall Accuracy, Kappa and 95\% confidence interval (CI) to demonstrate how accurately the classifier distinguishes between buy, sell and hold. In Table V NBG is able to classify buy, sell and hold decision compared to other three algorithms. In Table VI NBG performs best with $99 \%$ in almost all the fifteen cryptocurrency.

Table III. buy-sell-hold decision

\begin{tabular}{|c|c|c|c|}
\hline Cryptocurrency & Buy & Sell & Hold \\
\hline Binance Coin (BCN) & 287 & 27 & 604 \\
\hline BitCoin Cash (BCH) & 45 & 323 & 550 \\
\hline BitCoin (BTC) & 292 & 0 & 626 \\
\hline BitCoinSV (BSV) & 268 & 81 & 569 \\
\hline Cardano (CDO) & 0 & 497 & 421 \\
\hline Chainlink (CLK) & 3 & 278 & 637 \\
\hline CryptoCoin (CCN) & 0 & 291 & 627 \\
\hline EOS (EOS) & 8 & 308 & 602 \\
\hline Ethereum (ETH) & 316 & 4 & 598 \\
\hline LiteCoin (LTC) & 201 & 142 & 575 \\
\hline Monero (MNO) & 250 & 77 & 591 \\
\hline Stellar (SLR) & 0 & 286 & 632 \\
\hline Tether (TTR) & 0 & 298 & 620 \\
\hline Tezos (TZS) & 0 & 262 & 656 \\
\hline XRP (XRP) & 0 & 320 & 598 \\
\hline
\end{tabular}

\section{Conclusions}

Because of inaccurate policy making, classification of cryptocurrency is very difficult. Nevertheless, machine learning techniques have been successful in cryptocurrency classification in recent years. Several algorithms, for example gradient boosting, neural network, and so on were explored for strength in the classification of crypto-market decision strategy. However, removing noise from data have remained unexploited in this field. In this paper, we have used auto encoder for detecting strategy of buy, sell and hold and noise filter algorithms to remove noise from all the cryptocurrency dataset utilized in this study. In addition, NBG classification model has produced very impressive results for our predictive model. The technique has proven very effective in buying, selling and holding decision. Our model performance is assessed through several parameters such as sensitivity, specificity, PPV, NPV, balanced accuracy, overall accuracy, kappa and $95 \%$ confidence interval. For all the fifteen cryptocurrency datasets we have used for example, BCN, BCH, BTC, BSV, CDO, CLK, CCN, EOS, ETH, LTC, MNO, SLR, TTR, TZS, and XRP, we were able to achieve accuracy in the range $88-100 \%$. We also observed that COVID-19 has great impact in demand and supply of cryptocurrency during the global pandemic of COVID-19 that ravages the whole world.

\section{Acknowledgment}

We thank the anonymous reviewers for all their comments that has helped in improving this manuscript.

\section{References}

[1] Conway L. "The 10 most important cyryptocurrencies other than bitcoin, Retrieved from https://www.investopedia.com/tech/most-importantcryptocurrencies-other-than-bitcoin/, 2021"

[2] Tran V. and Leirvik, T. "Efficiency in the markets of cryptocurrencies" Finance Research Letters, 35 (2020) 101382.

[3] Giudici, G., Milne, A., and Vinogradov, D. (2020). "Cryptocurrencies: market analysis and perspectives", Journal of Industrial and Business Economics, 47:1-18, 2020.

[4] Oyewola, D.O, Augustine, F.E, Dada, E.G and Ibrahim, A. "Predicting Impact of COVID-19 on Crude Oil Price Image with Directed Acyclic Graph Deep Convolutional Neural Network", Journal of Robotics and Control (JRC), 2(2): 103109, 2021.

[5] Demir, E., Mehmet Huseyin Bilgin, M.H, Karabulut, G. and Doker, A.C. "The relationship between cryptocurrencies and COVID-19 Pandemic", Eurasian Economic Review, 10:349_ 360, 2020.

[6] Emna Mnif Assistant Professor , Anis Jarboui Professor, Khaireddine Mouakhar Professor, "How the cryptocurrency market has performed during COVID 19?A multifractal analysis", Finance Research Letter, 2020 doi: https://doi.org/10.1016/j.frl.2020.101647.

[7] Najaf, I., Fareed, Z., Wan, G. and Shahzad, F. "Asymmetric nexus between COVID-19 outbreak in the world and cryptocurrency market", International Review of financial Analysis, 73, 101613, 2021.

[8] Aysan, Ahmet Faruk, Asad UI Islam Khan, and Humeyra Topuz. "Bitcoin and Altcoins Price Dependency: Resilience and Portfolio Allocation in COVID-19". Outbreak.Risks 9: 74 2020. https://doi.org/10.3390/risks9040074

[9] Helder Sebastião and Pedro Godinho. "Forecasting and trading cryptocurrencies with machine learning under changing market conditions", Financ Innov, 7(3):1-10, 2021.

[10] Laura Alessandretti , Abeer ElBahrawy , Luca Maria Aiello ,and Andrea Baronchelli, "Anticipating Cryptocurrency Prices Using Machine Learning", Hindawi Complexity,1-16, 2018.

[11] Thomas E. Koker and Dimitrios Koutmos. "Cryptocurrency Trading Using Machine Learning", Journal of Risk and Financial Management, 13 (178): 1-7, 2020.

[12] David O. Oyewola , Asabe Ibrahim, Joshua.A. Kwanamu, Emmanuel Gbenga Dada (2021). A new auditory algorithm in stock market prediction on oil and gas sector in Nigerian stock exchange. Soft computing letters, 3 (2021) 100013

[13] WHO. Novel Coronavirus-China. https://www.who.int/csr/don/12-january-2020-novelcoronavirus-china/en/. (Accessed 29 March 2020).

[14] https://www.worldometers.info/coronavirus/ (Accessed on 14 May 2020)

[15] Han, J., Kamber, M., and Pei, J. "Data Mining Concepts and Techniques" (3rd ed). USA: Elsevier Inc, 2012.

[16] Pang, S., and Gong, J. "C5.0 Classification Algorithm and Application on Individual Credit Evaluation of Banks". Systems Engineering - Theory \& Practice, 29(12), 94-104.

[17] David .O. Oyewola, Emmanuel Gbenga Dada, Oluwatosin Temidayo Omotehinwa and Isa.A.Ibrahim. "Comparative Analysis of Linear, Non Linear and Ensemble Machine Learning Algorithms for Credit Worthiness of Consumers", Computational Intelligence \& Wireless Networks, 1(1), 1-11, 
2019

[18] José A. Sáez, M. Galar, J. Luengo, F. Herrera, “An iterative class noise filter based on the fusion of classifiers with noise sensitivity control", Information Fusion, 27 19-32, 2016. doi: 10.1016/j.inffus.2015.04.002.

[19] Ferhat Ozgur Catak, "Robust Ensemble Classifier Combination Based On Noise Removal with One-Class SVM", ICONIP 2015 Springer International Publishing Switzerland 2015, Part II, LNCS 9490, Pp. 10-17, 2015.

[20] Ronaldo C. Prati et al. "Emerging Topics and Challenges of Learning from Noisy Data in Nonstandard Classification: A Survey Beyond Binary Class Noise", Knowledge and Information Systems, Springer-Verlag London Ltd., Part Of Springer Nature, 2018.

[21] X. Wu and X. Zhu "Mining with Noise Knowledge: ErrorAware Data Mining", IEEE Transactions on Systems, Man, And Cybernetics 38, 917-932, 2008.

[22] Diego García-Gil , Julián Luengo , Salvador García and Francisco Herrera. "Enabling Smart Data: Noise filtering in Big Data classification”, Information Sciences 479 135-152, 2019.

[23] Tomek I. "An Experiment with the Edited Nearest-Neighbor Rule, in Systems, Man and Cybernetics", IEEE Transactions on, vol.SMC-6, no.6, pp. 448-452, 1976.

[24] Erdinc Akyildirim, Oguzhan Cepni, Shaen Corbet and Gazi Salah Uddin. "Forecasting mid-price movement of Bitcoin futures using machine learning", Annals of Operations Research, 2021. https://doi.org/10.1007/s10479-021-04205-x.

[25] Mohammed Mudassir, Shada Bennbaia, Devrim Unal and Mohammad Hammoudeh."Time-series forecasting of Bitcoin prices using high-dimensional features: a machine learning approach", Neural Computing and Applications, 2020. https://doi.org/10.1007/s00521-020-05129-6. 
Table II. Summary Statistics of Closing Price of Cryptocurrency

\begin{tabular}{|c|c|c|c|c|c|c|c|}
\hline ryptocurrency & Minimum & $1^{\text {st }}$ Quartile & Median & Mean & $3^{\text {rd }}$ Quartile & $\begin{array}{c}\text { Maximum } \\
\text { deviation }\end{array}$ \\
\hline Binance Coin (BCN) & 4.516 & 10.458 & 15.123 & 15.975 & 19.163 & 38.650 \\
\hline BitCoin Cash (BCH) & 78.35 & 226.51 & 306.74 & 440.41 & 519.68 & 1760.31 \\
\hline BitCoin (BTC) & 3229 & 6375 & 7700 & 7666 & 9299 & 17172 & 2367.341 \\
\hline BitCoinSV (BSV) & 15.49 & 73.96 & 106.06 & 122.80 & 169.41 & 425.36 & 66.85932 \\
\hline Cardano (CDO) & 0.0200 & 0.0400 & 0.0700 & 0.09431 & 0.10750 & 0.4600 & 0.079783 \\
\hline Chainlink (CLK) & 0.160 & 0.400 & 0.685 & 1.719 & 2.587 & 10.200 & 1.768353 \\
\hline CryptoCoin (CCN) & 0.00200 & 0.01090 & 0.03430 & 0.03927 & 0.05828 & 0.17430 & 0.0358074 \\
\hline EOS (EOS) & 1.746 & 2.754 & 4.028 & 5.003 & 5.930 & 21.418 & 3.084323 \\
\hline Ethereum (ETH) & 83.81 & 161.51 & 209.82 & 302.84 & 310.51 & 1380.00 & 238.8569 \\
\hline LiteCoin (LTC) & 23.21 & 44.90 & 59.02 & 74.04 & 88.50 & 228.70 & 40.63152 \\
\hline Monero (MNO) & 32.11 & 56.57 & 72.98 & 96.11 & 109.59 & 371.65 & 60.70651 \\
\hline Stellar (SLR) & 0.03243 & 0.06840 & 0.10169 & 0.14264 & 0.21630 & 0.47279 & 0.098484 \\
\hline Tether (TTR) & 0.9506 & 0.9990 & 1.0007 & 0.9998 & 1.0031 & 1.0288 \\
\hline Tezos (TZS) & 0.344 & 1.054 & 1.420 & 1.845 & 2.717 & 0.007308 \\
\hline XRP(XRP) & 0.1360 & 0.2433 & 0.3120 & 0.3726 & 0.4500 & 1.1781 & 0.1890485 \\
\hline
\end{tabular}


Table IV. Impact of COVID-19 on Cryptocurrency

\begin{tabular}{|c|c|c|c|c|c|c|}
\hline \multirow[t]{2}{*}{ Cryptocurrency } & \multicolumn{3}{|c|}{6 months before COVID-19 } & \multicolumn{3}{|c|}{6 months during COVID-19 } \\
\hline & Buy & Sell & Hold & Buy & Sell & Hold \\
\hline Binance Coin $(\mathrm{BCN})$ & 60 & 4 & 120 & 55 & 4 & 125 \\
\hline BitCoin Cash $(\mathrm{BCH})$ & 7 & 69 & 108 & 8 & 52 & 124 \\
\hline BitCoin (BTC) & 57 & 0 & 127 & 49 & 0 & 135 \\
\hline BitCoinSV (BSV) & 55 & 15 & 114 & 42 & 14 & 128 \\
\hline Cardano (CDO) & 0 & 96 & 88 & 0 & 89 & 95 \\
\hline Chainlink (CLK) & 0 & 54 & 130 & 1 & 45 & 138 \\
\hline CryptoCoin $(\mathrm{CCN})$ & 0 & 56 & 128 & 0 & 47 & 137 \\
\hline EOS (EOS) & 1 & 60 & 123 & 1 & 58 & 125 \\
\hline Ethereum (ETH) & 62 & 1 & 121 & 60 & 2 & 122 \\
\hline LiteCoin (LTC) & 38 & 33 & 113 & 39 & 22 & 123 \\
\hline Monero (MNO) & 49 & 17 & 118 & 49 & 11 & 124 \\
\hline Stellar (SLR) & 0 & 58 & 126 & 0 & 54 & 130 \\
\hline Tether (TTR) & 0 & 59 & 125 & 0 & 46 & 138 \\
\hline Tezos (TZS) & 0 & 58 & 126 & 0 & 45 & 139 \\
\hline XRP (XRP) & 0 & 64 & 120 & 0 & 60 & 124 \\
\hline
\end{tabular}


Oyewola et al., International Journal of Applied Mathematics Electronics and Computers 09(03): 052-066, 2021

\begin{tabular}{|c|c|c|c|c|c|c|c|c|c|c|c|c|c|c|c|c|}
\hline \multirow{2}{*}{$\begin{array}{c}\text { Cryptocurre } \\
\text { ncy }\end{array}$} & & \multicolumn{3}{|c|}{ Sensitivity } & \multicolumn{3}{|c|}{ Specificity } & \multicolumn{3}{|c|}{ PPV } & \multicolumn{3}{|c|}{ NPV } & \multicolumn{3}{|c|}{ Accuracy } \\
\hline & & Buy & Sell & Hold & Buy & Sell & hold & Buy & Sell & $\begin{array}{c}\mathrm{Hol} \\
\mathrm{d}\end{array}$ & Buy & Sell & hold & Buy & Sell & hold \\
\hline \multirow[t]{9}{*}{$\mathrm{BCH}$} & $\mathrm{NB}$ & 0.00 & $\begin{array}{c}30.1 \\
9\end{array}$ & 65.62 & 100 & 65.44 & $\begin{array}{c}31.1 \\
5\end{array}$ & - & $\begin{array}{c}25.3 \\
9\end{array}$ & $\begin{array}{c}66.6 \\
7\end{array}$ & $\begin{array}{c}95.7 \\
7\end{array}$ & $\begin{array}{c}70.6 \\
4\end{array}$ & $\begin{array}{c}30.1 \\
6\end{array}$ & $\begin{array}{c}50.0 \\
0\end{array}$ & $\begin{array}{c}47.8 \\
2\end{array}$ & $\begin{array}{c}48.3 \\
9\end{array}$ \\
\hline & $\mathrm{C} 5$ & 0.00 & 0.00 & $\begin{array}{c}100.0 \\
0\end{array}$ & 100 & 100 & 0.00 & - & - & $\begin{array}{c}67.7 \\
2 \\
\end{array}$ & $\begin{array}{c}95.7 \\
7 \\
\end{array}$ & $\begin{array}{c}71.9 \\
6 \\
\end{array}$ & - & $\begin{array}{c}95.7 \\
7 \\
\end{array}$ & $\begin{array}{c}71.9 \\
6 \\
\end{array}$ & - \\
\hline & $\mathrm{BG}$ & 0.00 & $\begin{array}{c}24.5 \\
3 \\
\end{array}$ & 77.34 & 100 & 77.21 & $\begin{array}{c}24.5 \\
9 \\
\end{array}$ & - & $\begin{array}{c}29.5 \\
5 \\
\end{array}$ & $\begin{array}{c}68.2 \\
8 \\
\end{array}$ & $\begin{array}{c}95.7 \\
7 \\
\end{array}$ & $\begin{array}{c}34.0 \\
9 \\
\end{array}$ & $\begin{array}{c}72.4 \\
1 \\
\end{array}$ & $\begin{array}{c}50.0 \\
0 \\
\end{array}$ & $\begin{array}{c}50.8 \\
8 \\
\end{array}$ & $\begin{array}{c}50.9 \\
7 \\
\end{array}$ \\
\hline & $\mathrm{NBG}$ & 100 & $\begin{array}{c}97.3 \\
7 \\
\end{array}$ & 100 & 100 & 100 & $\begin{array}{c}97.6 \\
2 \\
\end{array}$ & 100 & 100 & $\begin{array}{c}99.3 \\
2 \\
\end{array}$ & 100 & $\begin{array}{c}99.3 \\
4 \\
\end{array}$ & 100 & 100 & $\begin{array}{c}98.6 \\
8 \\
\end{array}$ & $\begin{array}{c}98.8 \\
1 \\
\end{array}$ \\
\hline & SVM & 0.00 & 0.00 & $\begin{array}{c}100.0 \\
0\end{array}$ & $\begin{array}{c}100.0 \\
0\end{array}$ & $\begin{array}{c}100.0 \\
0\end{array}$ & 0.00 & - & - & $\begin{array}{c}67.7 \\
2 \\
\end{array}$ & $\begin{array}{c}95.7 \\
7\end{array}$ & $\begin{array}{c}71.9 \\
6 \\
\end{array}$ & - & $\begin{array}{c}50.0 \\
0\end{array}$ & $\begin{array}{c}50.0 \\
0 \\
\end{array}$ & $\begin{array}{c}50.0 \\
0\end{array}$ \\
\hline & $\mathrm{RF}$ & 0.00 & $\begin{array}{c}20.7 \\
5 \\
\end{array}$ & 78.12 & 100 & 78.68 & $\begin{array}{c}19.6 \\
7 \\
\end{array}$ & - & $\begin{array}{c}27.5 \\
7 \\
\end{array}$ & $\begin{array}{c}67.1 \\
1 \\
\end{array}$ & $\begin{array}{c}95.7 \\
7 \\
\end{array}$ & $\begin{array}{c}71.8 \\
1 \\
\end{array}$ & $\begin{array}{c}30.0 \\
0\end{array}$ & $\begin{array}{c}50.0 \\
0 \\
\end{array}$ & $\begin{array}{c}49.7 \\
2 \\
\end{array}$ & $\begin{array}{c}48.9 \\
0 \\
\end{array}$ \\
\hline & MLR & 0.00 & 0.00 & 100 & 100 & 100 & 0.00 & - & - & $\begin{array}{c}67.7 \\
2 \\
\end{array}$ & $\begin{array}{c}95.7 \\
7 \\
\end{array}$ & $\begin{array}{c}71.9 \\
6 \\
\end{array}$ & - & $\begin{array}{c}50.0 \\
0 \\
\end{array}$ & $\begin{array}{c}50.0 \\
0 \\
\end{array}$ & $\begin{array}{c}50.0 \\
0 \\
\end{array}$ \\
\hline & RNN & 0.00 & $\begin{array}{c}23.8 \\
4\end{array}$ & 80.91 & 100 & 80.17 & $\begin{array}{c}24.4 \\
6\end{array}$ & - & $\begin{array}{c}39.4 \\
9\end{array}$ & $\begin{array}{c}61.5 \\
5 \\
\end{array}$ & $\begin{array}{c}95.0 \\
1\end{array}$ & $\begin{array}{c}65.9 \\
8 \\
\end{array}$ & $\begin{array}{c}46.1 \\
5\end{array}$ & $\begin{array}{c}50.0 \\
0 \\
\end{array}$ & $\begin{array}{c}52.0 \\
4 \\
\end{array}$ & $\begin{array}{c}52.6 \\
8 \\
\end{array}$ \\
\hline & $\begin{array}{c}\text { LST } \\
\text { M }\end{array}$ & 0.00 & 0.00 & 100 & 100 & 100 & 0.00 & - & - & $\begin{array}{c}59.9 \\
1 \\
\end{array}$ & $\begin{array}{c}95.0 \\
9 \\
\end{array}$ & $\begin{array}{c}64.8 \\
1 \\
\end{array}$ & - & $\begin{array}{c}50.0 \\
0 \\
\end{array}$ & $\begin{array}{c}50.0 \\
0 \\
\end{array}$ & $\begin{array}{c}50.0 \\
0 \\
\end{array}$ \\
\hline \multirow[t]{9}{*}{$\mathrm{BCN}$} & $\mathrm{NB}$ & 3.64 & 0.00 & 95.38 & 95.52 & 100 & 3.39 & $\begin{array}{c}25.0 \\
0\end{array}$ & - & $\begin{array}{c}68.5 \\
1 \\
\end{array}$ & $\begin{array}{c}70.7 \\
2 \\
\end{array}$ & $\begin{array}{c}97.8 \\
8 \\
\end{array}$ & $\begin{array}{c}25.0 \\
0\end{array}$ & $\begin{array}{c}49.5 \\
8\end{array}$ & $\begin{array}{c}50.0 \\
0\end{array}$ & $\begin{array}{c}49.3 \\
9\end{array}$ \\
\hline & $\mathrm{C} 5$ & 0.00 & 0.00 & 100 & 100 & 100 & 0.00 & - & - & $\begin{array}{c}68.7 \\
8 \\
\end{array}$ & $\begin{array}{c}70.9 \\
0 \\
\end{array}$ & $\begin{array}{c}97.8 \\
8 \\
\end{array}$ & - & $\begin{array}{c}50.0 \\
0 \\
\end{array}$ & $\begin{array}{c}50.0 \\
0 \\
\end{array}$ & $\begin{array}{c}50.0 \\
0\end{array}$ \\
\hline & BG & $\begin{array}{c}18.1 \\
8\end{array}$ & 0.00 & 80.00 & 79.85 & 99.46 & $\begin{array}{c}20.3 \\
4 \\
\end{array}$ & $\begin{array}{c}27.0 \\
3 \\
\end{array}$ & 0.00 & $\begin{array}{c}68.8 \\
7 \\
\end{array}$ & $\begin{array}{c}70.3 \\
9 \\
\end{array}$ & $\begin{array}{c}97.8 \\
7 \\
\end{array}$ & $\begin{array}{c}31.5 \\
8 \\
\end{array}$ & $\begin{array}{c}49.0 \\
2 \\
\end{array}$ & $\begin{array}{c}49.7 \\
3 \\
\end{array}$ & $\begin{array}{c}50.1 \\
7 \\
\end{array}$ \\
\hline & NBG & $\begin{array}{c}92.8 \\
6 \\
\end{array}$ & - & 100 & 100 & 100 & $\begin{array}{c}92.8 \\
6 \\
\end{array}$ & 100 & - & $\begin{array}{c}98.7 \\
7 \\
\end{array}$ & $\begin{array}{c}98.7 \\
7 \\
\end{array}$ & - & 100 & $\begin{array}{c}96.4 \\
3 \\
\end{array}$ & - & $\begin{array}{c}96.4 \\
3 \\
\end{array}$ \\
\hline & SVM & 0.00 & 0.00 & $\begin{array}{c}100.0 \\
0 \\
\end{array}$ & $\begin{array}{c}100.0 \\
0 \\
\end{array}$ & $\begin{array}{c}100.0 \\
0 \\
\end{array}$ & 0.00 & - & - & $\begin{array}{c}68.7 \\
8 \\
\end{array}$ & $\begin{array}{c}70.9 \\
0 \\
\end{array}$ & $\begin{array}{c}97.8 \\
8 \\
\end{array}$ & - & $\begin{array}{c}50.0 \\
0 \\
\end{array}$ & $\begin{array}{c}50.0 \\
0 \\
\end{array}$ & $\begin{array}{c}50.0 \\
0 \\
\end{array}$ \\
\hline & $\mathrm{RF}$ & $\begin{array}{c}12.7 \\
3 \\
\end{array}$ & 0.00 & 82.31 & 82.09 & 99.46 & $\begin{array}{c}15.2 \\
5 \\
\end{array}$ & $\begin{array}{c}22.5 \\
8 \\
\end{array}$ & 0.00 & $\begin{array}{c}68.1 \\
5 \\
\end{array}$ & $\begin{array}{c}69.6 \\
2 \\
\end{array}$ & $\begin{array}{c}97.8 \\
7 \\
\end{array}$ & $\begin{array}{c}28.1 \\
2 \\
\end{array}$ & $\begin{array}{c}47.4 \\
2 \\
\end{array}$ & $\begin{array}{c}48.7 \\
8 \\
\end{array}$ & $\begin{array}{c}49.7 \\
3 \\
\end{array}$ \\
\hline & MLR & 0.00 & 0.00 & 100 & 100 & 100 & 0.00 & - & - & $\begin{array}{c}68.7 \\
8 \\
\end{array}$ & $\begin{array}{c}70.9 \\
0 \\
\end{array}$ & $\begin{array}{c}97.8 \\
8 \\
\end{array}$ & - & $\begin{array}{c}50.0 \\
0 \\
\end{array}$ & $\begin{array}{c}50.0 \\
0 \\
\end{array}$ & $\begin{array}{c}50.0 \\
0\end{array}$ \\
\hline & RNN & 0.00 & 100 & 1.49 & 100 & 1.24 & $\begin{array}{c}99.3 \\
6 \\
\end{array}$ & - & 2.98 & $\begin{array}{c}81.8 \\
2 \\
\end{array}$ & $\begin{array}{c}68.7 \\
4 \\
\end{array}$ & 100 & $\begin{array}{c}34.4 \\
0 \\
\end{array}$ & $\begin{array}{c}50.0 \\
0 \\
\end{array}$ & $\begin{array}{c}50.6 \\
2 \\
\end{array}$ & $\begin{array}{c}50.4 \\
3 \\
\end{array}$ \\
\hline & $\begin{array}{c}\text { LST } \\
\text { M }\end{array}$ & 0.00 & 0.00 & 100 & 100 & 100 & 0.00 & - & - & 65.8 & $\begin{array}{c}68.7 \\
4 \\
\end{array}$ & $\begin{array}{c}97.0 \\
6 \\
\end{array}$ & - & $\begin{array}{c}50.0 \\
0 \\
\end{array}$ & $\begin{array}{c}50.0 \\
0 \\
\end{array}$ & $\begin{array}{c}50.0 \\
0 \\
\end{array}$ \\
\hline \multirow[t]{9}{*}{ BSV } & $\mathrm{NB}$ & 9.52 & 0.00 & 86.47 & 87.76 & 99.43 & 8.93 & $\begin{array}{c}18.1 \\
8\end{array}$ & 0.00 & $\begin{array}{c}69.2 \\
8\end{array}$ & $\begin{array}{c}77.2 \\
5\end{array}$ & $\begin{array}{c}92.5 \\
5\end{array}$ & $\begin{array}{c}21.7 \\
4\end{array}$ & $\begin{array}{c}48.6 \\
4\end{array}$ & $\begin{array}{c}49.7 \\
1\end{array}$ & $\begin{array}{c}47.7 \\
0\end{array}$ \\
\hline & C5 & 0.00 & 0.00 & 100 & 100 & 100 & 0.00 & - & - & $\begin{array}{c}70.3 \\
7 \\
\end{array}$ & $\begin{array}{c}77.7 \\
8\end{array}$ & $\begin{array}{c}92.5 \\
9\end{array}$ & - & $\begin{array}{c}50.0 \\
0\end{array}$ & $\begin{array}{c}50.0 \\
0\end{array}$ & $\begin{array}{c}50.0 \\
0\end{array}$ \\
\hline & $\mathrm{BG}$ & $\begin{array}{c}14.2 \\
9 \\
\end{array}$ & 0.00 & 81.95 & 85.03 & 96.00 & $\begin{array}{c}19.6 \\
4 \\
\end{array}$ & 0.00 & $\begin{array}{c}21.4 \\
3 \\
\end{array}$ & 0.00 & $\begin{array}{c}70.7 \\
8 \\
\end{array}$ & $\begin{array}{c}77.6 \\
4 \\
\end{array}$ & $\begin{array}{c}92.3 \\
1 \\
\end{array}$ & $\begin{array}{c}49.6 \\
6 \\
\end{array}$ & $\begin{array}{c}48.0 \\
0 \\
\end{array}$ & $\begin{array}{c}50.8 \\
0 \\
\end{array}$ \\
\hline & NBG & $\begin{array}{c}98.3 \\
3 \\
\end{array}$ & 100 & 100 & 100 & 100 & $\begin{array}{c}98.4 \\
1 \\
\end{array}$ & 100 & 100 & $\begin{array}{c}99.7 \\
1 \\
\end{array}$ & $\begin{array}{c}99.7 \\
2 \\
\end{array}$ & 100 & 100 & $\begin{array}{c}99.1 \\
7 \\
\end{array}$ & 100 & $\begin{array}{c}99.2 \\
1 \\
\end{array}$ \\
\hline & SVM & 0.00 & 0.00 & $\begin{array}{c}100.0 \\
0 \\
\end{array}$ & $\begin{array}{c}100.0 \\
0 \\
\end{array}$ & $\begin{array}{c}100.0 \\
0 \\
\end{array}$ & 0.00 & - & - & $\begin{array}{c}70.3 \\
7 \\
\end{array}$ & $\begin{array}{c}77.7 \\
8 \\
\end{array}$ & $\begin{array}{c}92.5 \\
9 \\
\end{array}$ & - & $\begin{array}{c}50.0 \\
0 \\
\end{array}$ & $\begin{array}{c}50.0 \\
0 \\
\end{array}$ & $\begin{array}{c}50.0 \\
0 \\
\end{array}$ \\
\hline & $\mathrm{RF}$ & 9.52 & 0.00 & 88.72 & 90.48 & 98.29 & $\begin{array}{c}10.7 \\
1\end{array}$ & $\begin{array}{c}22.2 \\
2\end{array}$ & 0.00 & $\begin{array}{c}70.2 \\
4 \\
\end{array}$ & $\begin{array}{c}77.7 \\
8 \\
\end{array}$ & $\begin{array}{c}92.4 \\
7 \\
\end{array}$ & $\begin{array}{c}28.5 \\
7\end{array}$ & $\begin{array}{c}50.0 \\
0 \\
\end{array}$ & $\begin{array}{c}49.1 \\
4 \\
\end{array}$ & $\begin{array}{c}49.7 \\
2\end{array}$ \\
\hline & MLR & 0.00 & 0.00 & 100 & 100 & 100 & 0.00 & - & - & $\begin{array}{c}70.3 \\
7 \\
\end{array}$ & $\begin{array}{c}77.7 \\
8 \\
\end{array}$ & $\begin{array}{c}92.5 \\
9 \\
\end{array}$ & - & $\begin{array}{c}50.0 \\
0 \\
\end{array}$ & $\begin{array}{c}50.0 \\
0 \\
\end{array}$ & $\begin{array}{c}50.0 \\
0\end{array}$ \\
\hline & RNN & 100 & 100 & 100 & 100 & 100 & 100 & 100 & 100 & 100 & 100 & 100 & 100 & 100 & 100 & 100 \\
\hline & $\begin{array}{c}\text { LST } \\
\mathrm{M} \\
\end{array}$ & 0.00 & 0.00 & 100 & 100 & 100 & 0.00 & - & - & $\begin{array}{c}61.9 \\
8 \\
\end{array}$ & $\begin{array}{c}70.8 \\
1 \\
\end{array}$ & $\begin{array}{c}91.1 \\
8 \\
\end{array}$ & - & $\begin{array}{c}50.0 \\
0 \\
\end{array}$ & $\begin{array}{c}50.0 \\
0 \\
\end{array}$ & $\begin{array}{c}50.0 \\
0 \\
\end{array}$ \\
\hline \multirow[t]{9}{*}{ BTC } & NB & 2.04 & - & - & 100 & - & - & 100 & - & - & $\begin{array}{c}74.4 \\
7 \\
\end{array}$ & - & - & $\begin{array}{c}51.0 \\
2 \\
\end{array}$ & - & - \\
\hline & $\mathrm{C} 5$ & 0.00 & - & - & 100 & - & - & - & - & - & $\begin{array}{c}74.0 \\
7\end{array}$ & - & - & $\begin{array}{c}50.0 \\
0\end{array}$ & - & - \\
\hline & BG & $\begin{array}{c}16.3 \\
3 \\
\end{array}$ & - & - & 76.43 & - & - & $\begin{array}{c}19.5 \\
1 \\
\end{array}$ & - & - & $\begin{array}{c}72.3 \\
0 \\
\end{array}$ & - & - & $\begin{array}{c}46.3 \\
8 \\
\end{array}$ & - & - \\
\hline & $\mathrm{NBG}$ & $\begin{array}{c}96.1 \\
5 \\
\end{array}$ & - & - & 100 & - & - & 100 & - & - & $\begin{array}{c}99.3 \\
9 \\
\end{array}$ & - & - & $\begin{array}{c}98.0 \\
8 \\
\end{array}$ & - & - \\
\hline & SVM & 0.00 & - & - & 100 & - & - & - & - & - & $\begin{array}{c}74.0 \\
7 \\
\end{array}$ & - & - & $\begin{array}{c}50.0 \\
0 \\
\end{array}$ & - & - \\
\hline & $\mathrm{RF}$ & $\begin{array}{c}10.2 \\
0 \\
\end{array}$ & - & - & 82.86 & - & - & $\begin{array}{c}17.2 \\
4 \\
\end{array}$ & - & - & $\begin{array}{c}72.5 \\
0 \\
\end{array}$ & - & - & $\begin{array}{c}46.5 \\
3 \\
\end{array}$ & - & - \\
\hline & MLR & 0.00 & - & - & 100 & - & - & - & - & - & $\begin{array}{c}74.0 \\
7 \\
\end{array}$ & - & - & $\begin{array}{c}50.0 \\
0 \\
\end{array}$ & - & - \\
\hline & RNN & 0.00 & - & - & 100 & - & - & - & - & - & $\begin{array}{c}68.1 \\
9 \\
\end{array}$ & - & - & $\begin{array}{c}50.0 \\
0 \\
\end{array}$ & - & - \\
\hline & $\begin{array}{c}\text { LST } \\
\text { M }\end{array}$ & 3.42 & - & - & 100 & - & - & 100 & - & - & $\begin{array}{c}68.2 \\
7\end{array}$ & - & - & $\begin{array}{c}50.1 \\
7 \\
\end{array}$ & & \\
\hline
\end{tabular}


Oyewola et al., International Journal of Applied Mathematics Electronics and Computers 09(03): 052-066, 2021

\begin{tabular}{|c|c|c|c|c|c|c|c|c|c|c|c|c|c|c|c|c|}
\hline \multirow[t]{9}{*}{$\mathrm{CCN}$} & $\mathrm{NB}$ & - & - & 44.68 & - & - & $\begin{array}{c}45.8 \\
3\end{array}$ & - & - & $\begin{array}{c}70.7 \\
9\end{array}$ & - & - & $\begin{array}{c}22.0 \\
0\end{array}$ & - & - & $\begin{array}{c}45.2 \\
6\end{array}$ \\
\hline & $\mathrm{C} 5$ & - & - & 100 & - & - & 0.00 & - & - & $\begin{array}{c}74.6 \\
0 \\
\end{array}$ & - & - & - & - & - & $\begin{array}{c}50.0 \\
0 \\
\end{array}$ \\
\hline & BG & - & - & 62.41 & - & - & $\begin{array}{c}41.6 \\
7\end{array}$ & - & - & $\begin{array}{c}75.8 \\
6\end{array}$ & - & - & $\begin{array}{c}27.4 \\
0\end{array}$ & - & - & $\begin{array}{c}52.0 \\
4\end{array}$ \\
\hline & NBG & - & - & 100 & - & - & $\begin{array}{c}83.3 \\
3 \\
\end{array}$ & - & - & $\begin{array}{c}98.8 \\
8 \\
\end{array}$ & - & - & 100 & - & - & $\begin{array}{c}91.6 \\
7 \\
\end{array}$ \\
\hline & SVM & - & - & 100 & - & - & 0.00 & - & - & 74.6 & - & - & - & - & - & $\begin{array}{c}50.0 \\
0\end{array}$ \\
\hline & $\mathrm{RF}$ & - & - & 74.47 & - & - & $\begin{array}{c}20.8 \\
3 \\
\end{array}$ & - & - & $\begin{array}{c}73.4 \\
3 \\
\end{array}$ & - & - & $\begin{array}{c}21.7 \\
4 \\
\end{array}$ & - & - & $\begin{array}{c}47.6 \\
5 \\
\end{array}$ \\
\hline & MLR & - & - & 0.00 & - & - & 100 & - & - & $\begin{array}{c}74.6 \\
0 \\
\end{array}$ & - & - & - & - & - & $\begin{array}{c}50.0 \\
0\end{array}$ \\
\hline & RNN & - & - & 100 & - & - & 0.00 & - & - & 68.3 & - & - & - & - & - & $\begin{array}{c}50.0 \\
0\end{array}$ \\
\hline & $\begin{array}{c}\text { LST } \\
\text { M }\end{array}$ & - & - & 100 & - & - & 0.00 & - & - & 68.3 & - & - & - & - & - & $\begin{array}{c}50.0 \\
0\end{array}$ \\
\hline \multirow[t]{9}{*}{ CDO } & NB & - & - & 0.00 & - & - & 100 & - & - & - & - & - & $\begin{array}{c}47.6 \\
2 \\
\end{array}$ & - & - & $\begin{array}{c}50.0 \\
0\end{array}$ \\
\hline & C5 & - & - & 0.00 & - & - & 100 & - & - & - & - & - & $\begin{array}{c}47.6 \\
2\end{array}$ & - & - & $\begin{array}{c}50.0 \\
0\end{array}$ \\
\hline & BG & - & - & 44.44 & - & - & $\begin{array}{c}61.1 \\
1 \\
\end{array}$ & - & - & $\begin{array}{c}55.7 \\
0 \\
\end{array}$ & - & - & $\begin{array}{c}50.0 \\
0 \\
\end{array}$ & - & - & $\begin{array}{c}52.7 \\
8 \\
\end{array}$ \\
\hline & NBG & - & - & 100 & - & - & 100 & - & - & 100 & - & - & 100 & - & - & 100 \\
\hline & SVM & - & - & 0.00 & - & - & 100 & - & - & - & - & - & $\begin{array}{c}47.6 \\
2\end{array}$ & - & - & $\begin{array}{c}50.0 \\
0\end{array}$ \\
\hline & $\mathrm{RF}$ & - & - & 43.43 & - & - & $\begin{array}{c}67.7 \\
8 \\
\end{array}$ & - & - & $\begin{array}{c}59.7 \\
2 \\
\end{array}$ & - & - & $\begin{array}{c}52.1 \\
4 \\
\end{array}$ & - & - & $\begin{array}{c}55.6 \\
1 \\
\end{array}$ \\
\hline & MLR & - & - & 0.00 & - & - & 100 & - & - & - & - & - & $\begin{array}{c}47.6 \\
2\end{array}$ & - & - & $\begin{array}{c}50.0 \\
0\end{array}$ \\
\hline & RNN & - & $\begin{array}{c}99.6 \\
0 \\
\end{array}$ & - & - & 0.00 & - & - & $\begin{array}{c}54.0 \\
4 \\
\end{array}$ & - & - & 0.00 & - & - & $\begin{array}{c}49.8 \\
0 \\
\end{array}$ & - \\
\hline & $\begin{array}{c}\text { LST } \\
\mathrm{M}\end{array}$ & - & 100 & - & - & 0.00 & - & - & $\begin{array}{c}54.1 \\
4 \\
\end{array}$ & - & - & - & - & - & $\begin{array}{c}50.0 \\
0 \\
\end{array}$ & - \\
\hline \multirow[t]{9}{*}{ CLK } & NB & 100 & 8.51 & 32.62 & 39.36 & 95.07 & $\begin{array}{c}64.5 \\
8\end{array}$ & 0.87 & $\begin{array}{c}36.3 \\
6\end{array}$ & $\begin{array}{c}73.0 \\
2 \\
\end{array}$ & 100 & $\begin{array}{c}75.8 \\
4\end{array}$ & $\begin{array}{c}24.6 \\
0\end{array}$ & $\begin{array}{c}69.6 \\
8\end{array}$ & $\begin{array}{c}51.7 \\
9 \\
\end{array}$ & $\begin{array}{c}48.6 \\
0\end{array}$ \\
\hline & C5 & 0.00 & 0.00 & 100 & 100 & 100 & 0.00 & - & - & $\begin{array}{c}75.1 \\
3 \\
\end{array}$ & $\begin{array}{c}99.4 \\
7 \\
\end{array}$ & $\begin{array}{c}75.1 \\
3 \\
\end{array}$ & - & $\begin{array}{c}50.0 \\
0 \\
\end{array}$ & $\begin{array}{c}50.0 \\
0 \\
\end{array}$ & $\begin{array}{c}50.0 \\
0 \\
\end{array}$ \\
\hline & BG & 0.00 & $\begin{array}{c}10.6 \\
4 \\
\end{array}$ & 84.40 & 100 & 84.51 & $\begin{array}{c}10.4 \\
2 \\
\end{array}$ & - & $\begin{array}{c}18.5 \\
2 \\
\end{array}$ & $\begin{array}{c}73.4 \\
6 \\
\end{array}$ & $\begin{array}{c}99.4 \\
7 \\
\end{array}$ & $\begin{array}{c}74.0 \\
7 \\
\end{array}$ & $\begin{array}{c}18.5 \\
2 \\
\end{array}$ & $\begin{array}{c}50.0 \\
0 \\
\end{array}$ & $\begin{array}{c}47.5 \\
7 \\
\end{array}$ & $\begin{array}{c}47.4 \\
1 \\
\end{array}$ \\
\hline & NBG & - & $\begin{array}{c}76.9 \\
2 \\
\end{array}$ & 92.61 & 100 & 92.61 & $\begin{array}{c}76.9 \\
2 \\
\end{array}$ & - & $\begin{array}{c}43.4 \\
8 \\
\end{array}$ & $\begin{array}{c}98.1 \\
9 \\
\end{array}$ & - & $\begin{array}{c}98.1 \\
9 \\
\end{array}$ & $\begin{array}{c}43.4 \\
8 \\
\end{array}$ & - & $\begin{array}{c}98.1 \\
9 \\
\end{array}$ & $\begin{array}{c}43.4 \\
8 \\
\end{array}$ \\
\hline & SVM & - & 0.00 & 100 & 100 & 100 & 0.00 & - & - & 74.6 & - & 74.6 & - & - & $\begin{array}{c}50.0 \\
0 \\
\end{array}$ & $\begin{array}{c}50.0 \\
0 \\
\end{array}$ \\
\hline & RF & - & $\begin{array}{c}12.5 \\
0 \\
\end{array}$ & 90.78 & 100 & 90.78 & $\begin{array}{c}12.5 \\
0 \\
\end{array}$ & - & $\begin{array}{c}31.5 \\
7 \\
\end{array}$ & $\begin{array}{c}75.2 \\
9 \\
\end{array}$ & - & $\begin{array}{c}75.2 \\
9 \\
\end{array}$ & $\begin{array}{c}31.5 \\
8 \\
\end{array}$ & - & $\begin{array}{c}51.6 \\
4 \\
\end{array}$ & $\begin{array}{c}51.6 \\
4 \\
\end{array}$ \\
\hline & MLR & - & 0.00 & 96.45 & 100 & 96.45 & 0.00 & - & 0.00 & $\begin{array}{c}73.9 \\
1 \\
\end{array}$ & - & $\begin{array}{c}73.9 \\
1 \\
\end{array}$ & 0.00 & - & $\begin{array}{c}48.2 \\
3 \\
\end{array}$ & $\begin{array}{c}48.2 \\
3 \\
\end{array}$ \\
\hline & RNN & 0.00 & 0.00 & 100 & 100 & 100 & 0.00 & - & - & $\begin{array}{c}69.3 \\
9 \\
\end{array}$ & $\begin{array}{c}99.6 \\
7 \\
\end{array}$ & $\begin{array}{c}69.7 \\
2 \\
\end{array}$ & - & $\begin{array}{c}50.0 \\
0 \\
\end{array}$ & $\begin{array}{c}50.0 \\
0 \\
\end{array}$ & $\begin{array}{c}50.0 \\
0 \\
\end{array}$ \\
\hline & $\begin{array}{c}\text { LST } \\
\mathrm{M} \\
\end{array}$ & 0.00 & 0.00 & 100 & 100 & 100 & 0.00 & - & - & $\begin{array}{c}69.3 \\
9 \\
\end{array}$ & $\begin{array}{c}99.6 \\
7 \\
\end{array}$ & $\begin{array}{c}69.7 \\
2 \\
\end{array}$ & - & $\begin{array}{c}50.0 \\
0 \\
\end{array}$ & $\begin{array}{c}50.0 \\
0 \\
\end{array}$ & $\begin{array}{c}50.0 \\
0 \\
\end{array}$ \\
\hline \multirow[t]{9}{*}{ EOS } & NB & 0.00 & 0.00 & 100 & 100 & 100 & 0.00 & - & - & $\begin{array}{c}68.7 \\
8 \\
\end{array}$ & $\begin{array}{c}99.4 \\
7 \\
\end{array}$ & $\begin{array}{c}69.3 \\
1 \\
\end{array}$ & - & $\begin{array}{c}50.0 \\
0 \\
\end{array}$ & $\begin{array}{c}50.0 \\
0 \\
\end{array}$ & $\begin{array}{c}50.0 \\
0 \\
\end{array}$ \\
\hline & C5 & 0.00 & 0.00 & 100 & 100 & 100 & 0.00 & - & - & $\begin{array}{c}68.7 \\
8 \\
\end{array}$ & $\begin{array}{c}99.4 \\
7\end{array}$ & $\begin{array}{c}69.3 \\
1 \\
\end{array}$ & - & $\begin{array}{c}50.0 \\
0 \\
\end{array}$ & $\begin{array}{c}50.0 \\
0\end{array}$ & $\begin{array}{c}50.0 \\
0\end{array}$ \\
\hline & NB & 0.00 & $\begin{array}{c}37.9 \\
3 \\
\end{array}$ & 65.38 & 100 & 65.66 & $\begin{array}{c}37.2 \\
9 \\
\end{array}$ & - & $\begin{array}{c}32.8 \\
4\end{array}$ & $\begin{array}{c}69.6 \\
7 \\
\end{array}$ & $\begin{array}{c}99.4 \\
7 \\
\end{array}$ & $\begin{array}{c}70.4 \\
9 \\
\end{array}$ & $\begin{array}{c}32.8 \\
4\end{array}$ & $\begin{array}{c}50.0 \\
0 \\
\end{array}$ & $\begin{array}{c}51.7 \\
9 \\
\end{array}$ & $\begin{array}{c}51.3 \\
4 \\
\end{array}$ \\
\hline & NBG & - & $\begin{array}{c}92.5 \\
9 \\
\end{array}$ & 100 & 100 & 100 & $\begin{array}{c}92.5 \\
9 \\
\end{array}$ & - & 100 & $\begin{array}{c}98.7 \\
8 \\
\end{array}$ & - & $\begin{array}{c}98.7 \\
8 \\
\end{array}$ & 100 & - & $\begin{array}{c}96.6 \\
3 \\
\end{array}$ & $\begin{array}{c}96.6 \\
3 \\
\end{array}$ \\
\hline & SVM & 0.00 & 0.00 & 100 & 100 & 100 & 0.00 & - & - & $\begin{array}{c}68.7 \\
8 \\
\end{array}$ & $\begin{array}{c}99.4 \\
7\end{array}$ & $\begin{array}{c}69.3 \\
1 \\
\end{array}$ & - & $\begin{array}{c}50.0 \\
0\end{array}$ & $\begin{array}{c}50.0 \\
0 \\
\end{array}$ & $\begin{array}{c}50.0 \\
0\end{array}$ \\
\hline & $\mathrm{RF}$ & 0.00 & $\begin{array}{c}31.0 \\
3 \\
\end{array}$ & 65.38 & 100 & 65.64 & $\begin{array}{c}30.5 \\
1 \\
\end{array}$ & - & $\begin{array}{c}28.5 \\
8 \\
\end{array}$ & $\begin{array}{c}67.4 \\
6 \\
\end{array}$ & $\begin{array}{c}99.4 \\
7 \\
\end{array}$ & $\begin{array}{c}68.2 \\
5 \\
\end{array}$ & $\begin{array}{c}28.5 \\
7 \\
\end{array}$ & $\begin{array}{c}50.0 \\
0 \\
\end{array}$ & $\begin{array}{c}48.3 \\
4 \\
\end{array}$ & $\begin{array}{c}47.9 \\
5 \\
\end{array}$ \\
\hline & MLR & 0.00 & 0.00 & 100 & 100 & 100 & 0.00 & - & - & $\begin{array}{c}68.7 \\
8 \\
\end{array}$ & $\begin{array}{c}99.4 \\
7 \\
\end{array}$ & $\begin{array}{c}69.3 \\
1 \\
\end{array}$ & - & $\begin{array}{c}50.0 \\
0 \\
\end{array}$ & $\begin{array}{c}50.0 \\
0 \\
\end{array}$ & $\begin{array}{c}50.0 \\
0 \\
\end{array}$ \\
\hline & RNN & 0.00 & 0.00 & 100 & 100 & 100 & 0.00 & - & - & $\begin{array}{c}65.5 \\
8 \\
\end{array}$ & $\begin{array}{c}99.1 \\
3 \\
\end{array}$ & $\begin{array}{c}66.4 \\
5 \\
\end{array}$ & - & $\begin{array}{c}50.0 \\
0 \\
\end{array}$ & $\begin{array}{c}50.0 \\
0 \\
\end{array}$ & $\begin{array}{c}50.0 \\
0 \\
\end{array}$ \\
\hline & $\begin{array}{c}\text { LST } \\
\mathrm{M} \\
\end{array}$ & 0.00 & 0.00 & 100 & 100 & 100 & 0.00 & - & - & $\begin{array}{c}65.5 \\
8 \\
\end{array}$ & $\begin{array}{c}99.1 \\
3 \\
\end{array}$ & $\begin{array}{c}66.4 \\
5 \\
\end{array}$ & - & $\begin{array}{c}50.0 \\
0 \\
\end{array}$ & $\begin{array}{c}50.0 \\
0 \\
\end{array}$ & $\begin{array}{c}50.0 \\
0 \\
\end{array}$ \\
\hline \multirow[t]{3}{*}{ ETH } & NB & 0.00 & 0.00 & 100 & 100 & 100 & 0.00 & - & - & 67.2 & $\begin{array}{c}68.2 \\
5 \\
\end{array}$ & $\begin{array}{c}98.9 \\
4 \\
\end{array}$ & - & $\begin{array}{c}50.0 \\
0 \\
\end{array}$ & $\begin{array}{c}50.0 \\
0 \\
\end{array}$ & $\begin{array}{c}50.0 \\
0 \\
\end{array}$ \\
\hline & $\mathrm{C} 5$ & 0.00 & 0.00 & 100 & 100 & 100 & 0.00 & - & - & 67.2 & $\begin{array}{c}68.8 \\
5 \\
\end{array}$ & $\begin{array}{c}98.9 \\
4 \\
\end{array}$ & - & $\begin{array}{c}50.0 \\
0 \\
\end{array}$ & $\begin{array}{c}50.0 \\
0 \\
\end{array}$ & $\begin{array}{c}50.0 \\
0 \\
\end{array}$ \\
\hline & BG & $\begin{array}{c}20.0 \\
0\end{array}$ & 0.00 & 77.95 & 78.30 & 100 & $\begin{array}{c}19.3 \\
5 \\
\end{array}$ & $\begin{array}{c}30.0 \\
0\end{array}$ & - & $\begin{array}{c}66.4 \\
4\end{array}$ & $\begin{array}{c}67.7 \\
9 \\
\end{array}$ & $\begin{array}{c}98.9 \\
4 \\
\end{array}$ & $\begin{array}{c}30.0 \\
0\end{array}$ & $\begin{array}{c}49.1 \\
5 \\
\end{array}$ & $\begin{array}{c}50.0 \\
0 \\
\end{array}$ & $\begin{array}{c}48.6 \\
5 \\
\end{array}$ \\
\hline
\end{tabular}


Oyewola et al., International Journal of Applied Mathematics Electronics and Computers 09(03): 052-066, 2021

\begin{tabular}{|c|c|c|c|c|c|c|c|c|c|c|c|c|c|c|c|c|}
\hline & NBG & $\begin{array}{c}67.7 \\
4 \\
\end{array}$ & - & 92.41 & 92.41 & 100 & $\begin{array}{c}67.7 \\
4 \\
\end{array}$ & $\begin{array}{c}63.6 \\
3 \\
\end{array}$ & - & $\begin{array}{c}93.5 \\
9 \\
\end{array}$ & $\begin{array}{c}93.5 \\
9 \\
\end{array}$ & - & $\begin{array}{c}63.6 \\
4 \\
\end{array}$ & $\begin{array}{c}80.0 \\
7 \\
\end{array}$ & $\begin{array}{c}80.0 \\
7 \\
\end{array}$ & - \\
\hline & SVM & 0.00 & 0.00 & 100 & 100 & 100 & 0.00 & - & - & 67.2 & $\begin{array}{c}68.2 \\
5 \\
\end{array}$ & $\begin{array}{c}98.9 \\
4 \\
\end{array}$ & - & $\begin{array}{c}50.0 \\
0 \\
\end{array}$ & $\begin{array}{c}50.0 \\
0 \\
\end{array}$ & $\begin{array}{c}50.0 \\
0\end{array}$ \\
\hline & $\mathrm{RF}$ & $\begin{array}{c}23.3 \\
3\end{array}$ & 0.00 & 74.80 & 75.19 & 100 & $\begin{array}{c}22.5 \\
8\end{array}$ & $\begin{array}{c}30.4 \\
4\end{array}$ & - & $\begin{array}{c}66.4 \\
3\end{array}$ & $\begin{array}{c}67.8 \\
3\end{array}$ & $\begin{array}{c}98.9 \\
4\end{array}$ & $\begin{array}{c}30.4 \\
3\end{array}$ & $\begin{array}{c}49.2 \\
6\end{array}$ & $\begin{array}{c}50.0 \\
0\end{array}$ & $\begin{array}{c}48.6 \\
9\end{array}$ \\
\hline & MLR & 0.00 & 0.00 & 100 & 100 & 100 & 0.00 & - & - & $\begin{array}{c}67.2 \\
0 \\
\end{array}$ & $\begin{array}{c}68.2 \\
5 \\
\end{array}$ & $\begin{array}{c}98.9 \\
4 \\
\end{array}$ & - & $\begin{array}{c}50.0 \\
0 \\
\end{array}$ & $\begin{array}{c}50.0 \\
0 \\
\end{array}$ & $\begin{array}{c}50.0 \\
0 \\
\end{array}$ \\
\hline & RNN & 0.00 & 100 & 0.00 & 100 & 0.00 & 100 & - & 0.45 & - & - & 0.44 & - & $\begin{array}{c}50.0 \\
0 \\
\end{array}$ & $\begin{array}{c}50.0 \\
0 \\
\end{array}$ & $\begin{array}{c}50.0 \\
0 \\
\end{array}$ \\
\hline & $\begin{array}{c}\text { LST } \\
\mathrm{M} \\
\end{array}$ & 0.32 & 0.00 & 100 & 100 & 100 & 0.31 & 100 & - & $\begin{array}{c}65.2 \\
1 \\
\end{array}$ & $\begin{array}{c}65.6 \\
5 \\
\end{array}$ & $\begin{array}{c}99.5 \\
6 \\
\end{array}$ & 100 & $\begin{array}{c}50.1 \\
6 \\
\end{array}$ & $\begin{array}{c}50.0 \\
0 \\
\end{array}$ & $\begin{array}{c}50.1 \\
6 \\
\end{array}$ \\
\hline \multirow[t]{9}{*}{ LTC } & $\mathrm{NB}$ & 0.00 & 0.00 & 100 & 100 & 100 & 0.00 & - & - & 67.2 & $\begin{array}{c}79.3 \\
7 \\
\end{array}$ & $\begin{array}{c}87.8 \\
3 \\
\end{array}$ & - & $\begin{array}{c}50.0 \\
0 \\
\end{array}$ & $\begin{array}{c}50.0 \\
0 \\
\end{array}$ & $\begin{array}{c}50.0 \\
0 \\
\end{array}$ \\
\hline & C5 & 0.00 & 0.00 & 100 & 100 & 100 & 0.00 & - & - & 67.2 & $\begin{array}{c}79.3 \\
7 \\
\end{array}$ & $\begin{array}{c}87.8 \\
3 \\
\end{array}$ & - & $\begin{array}{c}50.0 \\
0 \\
\end{array}$ & $\begin{array}{c}50.0 \\
0 \\
\end{array}$ & $\begin{array}{c}50.0 \\
0 \\
\end{array}$ \\
\hline & BG & $\begin{array}{c}15.3 \\
9 \\
\end{array}$ & 4.35 & 85.04 & 90.00 & 95.78 & $\begin{array}{c}16.1 \\
3 \\
\end{array}$ & $\begin{array}{c}28.5 \\
7 \\
\end{array}$ & $\begin{array}{c}12.5 \\
0 \\
\end{array}$ & $\begin{array}{c}67.5 \\
0 \\
\end{array}$ & $\begin{array}{c}80.3 \\
6 \\
\end{array}$ & $\begin{array}{c}87.8 \\
4 \\
\end{array}$ & $\begin{array}{c}34.4 \\
8 \\
\end{array}$ & $\begin{array}{c}52.6 \\
9 \\
\end{array}$ & $\begin{array}{c}50.0 \\
7 \\
\end{array}$ & $\begin{array}{c}50.5 \\
8 \\
\end{array}$ \\
\hline & $\mathrm{NBG}$ & 100 & 100 & 100 & 100 & 100 & 100 & 100 & 100 & 100 & 100 & 100 & 100 & 100 & 100 & 100 \\
\hline & SVM & 0.00 & 0.00 & 100 & 100 & 100 & 0.00 & - & - & 67.2 & $\begin{array}{c}79.3 \\
7 \\
\end{array}$ & $\begin{array}{c}87.8 \\
3 \\
\end{array}$ & - & $\begin{array}{c}50.0 \\
0 \\
\end{array}$ & $\begin{array}{c}50.0 \\
0 \\
\end{array}$ & $\begin{array}{c}50.0 \\
0 \\
\end{array}$ \\
\hline & RF & 7.69 & 4.35 & 88.98 & 93.33 & 96.39 & 9.68 & $\begin{array}{c}23.0 \\
8 \\
\end{array}$ & $\begin{array}{c}14.2 \\
9 \\
\end{array}$ & $\begin{array}{c}66.8 \\
6 \\
\end{array}$ & $\begin{array}{c}79.5 \\
5 \\
\end{array}$ & $\begin{array}{c}87.9 \\
1 \\
\end{array}$ & $\begin{array}{c}30.0 \\
0 \\
\end{array}$ & $\begin{array}{c}50.5 \\
1 \\
\end{array}$ & $\begin{array}{c}50.3 \\
7 \\
\end{array}$ & $\begin{array}{c}49.3 \\
3 \\
\end{array}$ \\
\hline & MLR & 0.00 & 0.00 & 100 & 100 & 100 & 0.00 & - & - & $\begin{array}{c}67.2 \\
0 \\
\end{array}$ & $\begin{array}{c}79.3 \\
7 \\
\end{array}$ & $\begin{array}{c}87.8 \\
3 \\
\end{array}$ & - & $\begin{array}{c}50.0 \\
0 \\
\end{array}$ & $\begin{array}{c}50.0 \\
0 \\
\end{array}$ & $\begin{array}{c}50.0 \\
0 \\
\end{array}$ \\
\hline & RNN & 0.00 & 100 & 0.00 & 100 & 0.00 & 100 & - & $\begin{array}{c}15.4 \\
7 \\
\end{array}$ & - & 78.1 & - & $\begin{array}{c}37.3 \\
6 \\
\end{array}$ & $\begin{array}{c}50.0 \\
0 \\
\end{array}$ & $\begin{array}{c}50.0 \\
0 \\
\end{array}$ & $\begin{array}{c}50.0 \\
0 \\
\end{array}$ \\
\hline & $\begin{array}{c}\text { LST } \\
\mathrm{M} \\
\end{array}$ & 0.00 & 0.00 & 100 & 100 & 98.7 & 0.29 & - & 0.00 & $\begin{array}{c}62.7 \\
0 \\
\end{array}$ & $\begin{array}{c}78.1 \\
0 \\
\end{array}$ & $\begin{array}{c}84.5 \\
1 \\
\end{array}$ & 100 & $\begin{array}{c}50.0 \\
0 \\
\end{array}$ & $\begin{array}{c}49.9 \\
3 \\
\end{array}$ & $\begin{array}{c}50.1 \\
5 \\
\end{array}$ \\
\hline \multirow[t]{9}{*}{ MNO } & NB & 0.00 & 0.00 & 100 & 100 & 100 & 0.00 & - & - & $\begin{array}{c}68.2 \\
5 \\
\end{array}$ & $\begin{array}{c}74.0 \\
7 \\
\end{array}$ & $\begin{array}{c}94.1 \\
8 \\
\end{array}$ & - & $\begin{array}{c}50.0 \\
0 \\
\end{array}$ & $\begin{array}{c}50.0 \\
0 \\
\end{array}$ & $\begin{array}{c}50.0 \\
0 \\
\end{array}$ \\
\hline & $\mathrm{C} 5$ & 0.00 & 0.00 & 100 & 100 & 100 & 0.00 & - & - & $\begin{array}{c}68.2 \\
5 \\
\end{array}$ & $\begin{array}{c}74.0 \\
7 \\
\end{array}$ & $\begin{array}{c}94.1 \\
8 \\
\end{array}$ & - & $\begin{array}{c}50.0 \\
0 \\
\end{array}$ & $\begin{array}{c}50.0 \\
0 \\
\end{array}$ & $\begin{array}{c}50.0 \\
0 \\
\end{array}$ \\
\hline & BG & $\begin{array}{c}18.3 \\
7 \\
\end{array}$ & 0.00 & 85.27 & 86.43 & 97.75 & $\begin{array}{c}21.6 \\
7 \\
\end{array}$ & $\begin{array}{c}32.1 \\
4 \\
\end{array}$ & 0.00 & $\begin{array}{c}70.0 \\
6 \\
\end{array}$ & $\begin{array}{c}75.1 \\
6 \\
\end{array}$ & $\begin{array}{c}94.0 \\
5 \\
\end{array}$ & $\begin{array}{c}40.6 \\
2 \\
\end{array}$ & $\begin{array}{c}52.4 \\
0 \\
\end{array}$ & $\begin{array}{c}48.8 \\
8 \\
\end{array}$ & $\begin{array}{c}53.4 \\
7 \\
\end{array}$ \\
\hline & NBG & 100 & 100 & 100 & 100 & 100 & 100 & 100 & 100 & 100 & 100 & 100 & 100 & 100 & 100 & 100 \\
\hline & SVM & 0.00 & 0.00 & 100 & 100 & 100 & 0.00 & - & - & $\begin{array}{c}68.2 \\
5 \\
\end{array}$ & $\begin{array}{c}74.0 \\
7 \\
\end{array}$ & $\begin{array}{c}94.1 \\
8 \\
\end{array}$ & - & $\begin{array}{c}50.0 \\
0\end{array}$ & $\begin{array}{c}50.0 \\
0\end{array}$ & $\begin{array}{c}50.0 \\
0\end{array}$ \\
\hline & $\mathrm{RF}$ & 1.02 & 9.09 & 90.70 & 92.14 & 95.51 & $\begin{array}{c}21.6 \\
7 \\
\end{array}$ & $\begin{array}{c}31.2 \\
5 \\
\end{array}$ & $\begin{array}{c}11.1 \\
1 \\
\end{array}$ & $\begin{array}{c}71.3 \\
4 \\
\end{array}$ & $\begin{array}{c}74.5 \\
7 \\
\end{array}$ & $\begin{array}{c}94.4 \\
4 \\
\end{array}$ & $\begin{array}{c}52.0 \\
0 \\
\end{array}$ & $\begin{array}{c}51.1 \\
7 \\
\end{array}$ & $\begin{array}{c}52.2 \\
9 \\
\end{array}$ & $\begin{array}{c}56.1 \\
8 \\
\end{array}$ \\
\hline & MLR & 0.00 & 0.00 & 100 & 100 & 100 & 0.00 & - & - & $\begin{array}{c}68.2 \\
5 \\
\end{array}$ & $\begin{array}{c}74.0 \\
7 \\
\end{array}$ & $\begin{array}{c}94.1 \\
8 \\
\end{array}$ & - & $\begin{array}{c}50.0 \\
0 \\
\end{array}$ & $\begin{array}{c}50.0 \\
0 \\
\end{array}$ & $\begin{array}{c}50.0 \\
0 \\
\end{array}$ \\
\hline & RNN & 0.00 & 100 & 0.00 & 100 & 0.00 & 100 & - & 8.38 & - & $\begin{array}{c}72.7 \\
7 \\
\end{array}$ & - & $\begin{array}{c}35.6 \\
2 \\
\end{array}$ & $\begin{array}{c}50.0 \\
0 \\
\end{array}$ & $\begin{array}{c}50.0 \\
0 \\
\end{array}$ & $\begin{array}{c}50.0 \\
0 \\
\end{array}$ \\
\hline & $\begin{array}{c}\text { LST } \\
\mathrm{M} \\
\end{array}$ & 0.00 & 100 & 0.00 & 100 & 100 & 0.00 & - & - & $\begin{array}{c}64.3 \\
8 \\
\end{array}$ & $\begin{array}{c}72.7 \\
7 \\
\end{array}$ & $\begin{array}{c}91.6 \\
2 \\
\end{array}$ & - & $\begin{array}{c}50.0 \\
0 \\
\end{array}$ & $\begin{array}{c}50.0 \\
0 \\
\end{array}$ & $\begin{array}{c}50.0 \\
0 \\
\end{array}$ \\
\hline \multirow[t]{9}{*}{ SLR } & $\mathrm{NB}$ & - & - & 100 & - & - & 0.00 & - & - & $\begin{array}{c}71.4 \\
3 \\
\end{array}$ & - & - & - & - & - & $\begin{array}{c}50.0 \\
0 \\
\end{array}$ \\
\hline & C5 & - & - & 100 & - & - & 0.00 & - & - & $\begin{array}{c}71.4 \\
3 \\
\end{array}$ & - & - & - & - & - & $\begin{array}{c}50.0 \\
0 \\
\end{array}$ \\
\hline & BG & - & - & 80.00 & - & - & $\begin{array}{c}11.1 \\
1 \\
\end{array}$ & - & - & $\begin{array}{c}69.2 \\
3 \\
\end{array}$ & - & - & $\begin{array}{c}18.1 \\
8 \\
\end{array}$ & - & - & $\begin{array}{c}45.5 \\
6 \\
\end{array}$ \\
\hline & NBG & - & - & 100 & - & - & 100 & - & - & 100 & - & - & 100 & - & - & 100 \\
\hline & SVM & - & - & 100 & - & - & 0.00 & - & - & $\begin{array}{c}71.4 \\
3 \\
\end{array}$ & - & - & - & - & - & $\begin{array}{c}50.0 \\
0 \\
\end{array}$ \\
\hline & $\mathrm{RF}$ & - & - & 80.74 & - & - & $\begin{array}{c}16.6 \\
7 \\
\end{array}$ & - & - & $\begin{array}{c}70.7 \\
8 \\
\end{array}$ & - & - & $\begin{array}{c}25.7 \\
1 \\
\end{array}$ & - & - & $\begin{array}{c}48.7 \\
0 \\
\end{array}$ \\
\hline & MLR & - & - & 100 & - & - & 0.00 & - & - & - & - & - & $\begin{array}{c}71.4 \\
3 \\
\end{array}$ & - & - & $\begin{array}{c}50.0 \\
0\end{array}$ \\
\hline & RNN & - & - & 100 & - & - & 0.00 & - & - & $\begin{array}{c}68.8 \\
5 \\
\end{array}$ & - & - & - & - & - & $\begin{array}{c}50.0 \\
0 \\
\end{array}$ \\
\hline & $\begin{array}{c}\text { LST } \\
\mathrm{M} \\
\end{array}$ & - & - & 100 & - & - & 0.00 & - & - & $\begin{array}{c}68.8 \\
5 \\
\end{array}$ & - & - & - & - & - & $\begin{array}{c}50.0 \\
0 \\
\end{array}$ \\
\hline \multirow[t]{7}{*}{ TTR } & $\mathrm{NB}$ & - & - & 100 & - & - & 0.00 & - & - & $\begin{array}{c}75.6 \\
6 \\
\end{array}$ & - & - & - & - & - & $\begin{array}{c}50.0 \\
0 \\
\end{array}$ \\
\hline & $\mathrm{C} 5$ & - & - & 100 & - & - & 0.00 & - & - & $\begin{array}{c}75.6 \\
6 \\
\end{array}$ & - & - & - & - & - & $\begin{array}{c}50.0 \\
0 \\
\end{array}$ \\
\hline & BG & - & - & 81.82 & - & - & 8.70 & - & - & $\begin{array}{c}73.5 \\
9 \\
\end{array}$ & - & - & $\begin{array}{c}13.3 \\
3 \\
\end{array}$ & - & - & $\begin{array}{c}45.2 \\
6 \\
\end{array}$ \\
\hline & NBG & - & - & 100 & - & - & 100 & - & - & 100 & - & - & 100 & - & - & 100 \\
\hline & SVM & - & - & 100 & - & - & 0.00 & - & - & $\begin{array}{c}75.6 \\
6 \\
\end{array}$ & - & - & - & - & - & $\begin{array}{c}50.0 \\
0 \\
\end{array}$ \\
\hline & $\mathrm{RF}$ & - & - & 83.92 & - & - & $\begin{array}{c}13.0 \\
4 \\
\end{array}$ & - & - & $\begin{array}{c}75.0 \\
0 \\
\end{array}$ & - & - & $\begin{array}{c}20.6 \\
9 \\
\end{array}$ & - & - & $\begin{array}{c}48.4 \\
8 \\
\end{array}$ \\
\hline & MLR & - & - & 100 & - & - & 0.00 & - & - & $\begin{array}{c}75.6 \\
6\end{array}$ & - & - & - & - & - & $\begin{array}{c}50.0 \\
0\end{array}$ \\
\hline
\end{tabular}


Oyewola et al., International Journal of Applied Mathematics Electronics and Computers 09(03): 052-066, 2021

\begin{tabular}{|c|c|c|c|c|c|c|c|c|c|c|c|c|c|c|c|c|}
\hline & RNN & - & 0.33 & - & - & 100 & - & - & 100 & - & - & $\begin{array}{c}67.6 \\
2\end{array}$ & - & - & $\begin{array}{c}50.1 \\
7\end{array}$ & - \\
\hline & $\begin{array}{c}\text { LST } \\
\text { M }\end{array}$ & - & - & 100 & - & - & 0.00 & - & - & $\begin{array}{c}67.5 \\
4\end{array}$ & - & - & - & - & - & $\begin{array}{c}50.0 \\
0\end{array}$ \\
\hline \multirow[t]{9}{*}{ TZS } & NB & - & - & 100 & - & - & 0.00 & - & - & $\begin{array}{c}76.1 \\
9 \\
\end{array}$ & - & - & - & - & - & $\begin{array}{c}50.0 \\
0\end{array}$ \\
\hline & C5 & - & - & 100 & - & - & 0.00 & - & - & $\begin{array}{c}76.1 \\
9\end{array}$ & - & - & - & - & - & $\begin{array}{c}50.0 \\
0\end{array}$ \\
\hline & BG & - & - & 73.61 & - & - & $\begin{array}{c}17.7 \\
8\end{array}$ & - & - & $\begin{array}{c}74.1 \\
3\end{array}$ & - & - & $\begin{array}{c}17.3 \\
9\end{array}$ & - & - & $\begin{array}{c}45.6 \\
9\end{array}$ \\
\hline & $\mathrm{NBG}$ & - & - & 100 & - & - & 100 & - & - & 100 & - & - & 100 & - & - & 100 \\
\hline & SVM & - & - & 100 & - & - & 0.00 & - & - & $\begin{array}{c}76.1 \\
9\end{array}$ & - & - & - & - & - & $\begin{array}{c}50.0 \\
0\end{array}$ \\
\hline & $\mathrm{RF}$ & - & - & 83.33 & - & - & $\begin{array}{c}11.1 \\
1 \\
\end{array}$ & - & - & $\begin{array}{c}75.0 \\
0 \\
\end{array}$ & - & - & $\begin{array}{c}17.2 \\
4 \\
\end{array}$ & - & - & $\begin{array}{c}47.2 \\
2 \\
\end{array}$ \\
\hline & MLR & - & - & 100 & - & - & 2.22 & - & - & $\begin{array}{c}76.6 \\
0 \\
\end{array}$ & - & - & 100 & - & - & $\begin{array}{c}51.1 \\
1 \\
\end{array}$ \\
\hline & RNN & 0.00 & 0.00 & 100 & 100 & 100 & 0.00 & - & - & $\begin{array}{c}71.4 \\
6 \\
\end{array}$ & $\begin{array}{c}99.8 \\
9 \\
\end{array}$ & $\begin{array}{c}71.5 \\
7 \\
\end{array}$ & - & $\begin{array}{c}50.0 \\
0 \\
\end{array}$ & $\begin{array}{c}50.0 \\
0 \\
\end{array}$ & $\begin{array}{c}50.0 \\
0 \\
\end{array}$ \\
\hline & $\begin{array}{c}\text { LST } \\
\text { M }\end{array}$ & 0.00 & 0.00 & 100 & 100 & 100 & 0.00 & - & - & $\begin{array}{c}71.4 \\
6 \\
\end{array}$ & $\begin{array}{c}98.8 \\
9 \\
\end{array}$ & $\begin{array}{c}71.5 \\
7 \\
\end{array}$ & - & $\begin{array}{c}50.0 \\
0 \\
\end{array}$ & $\begin{array}{c}50.0 \\
0 \\
\end{array}$ & $\begin{array}{c}50.0 \\
0 \\
\end{array}$ \\
\hline \multirow[t]{9}{*}{ XRP } & NB & - & - & 100 & - & - & 0.00 & - & - & $\begin{array}{c}68.2 \\
5 \\
\end{array}$ & - & - & - & - & - & $\begin{array}{c}50.0 \\
0\end{array}$ \\
\hline & C5 & - & - & 100 & - & - & 0.00 & - & - & $\begin{array}{c}68.2 \\
5 \\
\end{array}$ & - & - & - & - & - & $\begin{array}{c}50.0 \\
0 \\
\end{array}$ \\
\hline & BG & - & - & 86.05 & - & - & $\begin{array}{c}10.0 \\
0 \\
\end{array}$ & - & - & $\begin{array}{c}67.2 \\
7 \\
\end{array}$ & - & - & $\begin{array}{c}25.0 \\
0 \\
\end{array}$ & - & - & $\begin{array}{c}48.0 \\
2 \\
\end{array}$ \\
\hline & NBG & - & - & 100 & - & - & 100 & - & - & 100 & - & - & 100 & - & - & 100 \\
\hline & SVM & - & - & 100 & - & - & 0.00 & - & - & $\begin{array}{c}68.2 \\
5 \\
\end{array}$ & - & - & - & - & - & $\begin{array}{c}50.0 \\
0 \\
\end{array}$ \\
\hline & $\mathrm{RF}$ & - & - & 89.15 & - & - & 8.33 & - & - & $\begin{array}{c}67.6 \\
5 \\
\end{array}$ & - & - & $\begin{array}{c}26.3 \\
2 \\
\end{array}$ & - & - & $\begin{array}{c}48.7 \\
4 \\
\end{array}$ \\
\hline & MLR & - & - & 100 & - & - & 0.00 & - & - & $\begin{array}{c}68.2 \\
5 \\
\end{array}$ & - & - & - & - & - & $\begin{array}{c}50.0 \\
0\end{array}$ \\
\hline & RNN & - & - & 100 & - & - & 0.00 & - & - & $\begin{array}{c}65.1 \\
4 \\
\end{array}$ & - & - & - & - & - & $\begin{array}{c}50.0 \\
0 \\
\end{array}$ \\
\hline & $\begin{array}{c}\text { LST } \\
\text { M }\end{array}$ & - & - & 100 & - & - & 0.00 & - & - & $\begin{array}{c}65.1 \\
4 \\
\end{array}$ & - & - & - & - & - & $\begin{array}{c}50.0 \\
0\end{array}$ \\
\hline
\end{tabular}


Table VI. Performance Metrics of NB, C5, NBG, SVM, RF, MLR, RNN and LSTM

\begin{tabular}{|c|c|c|c|c|}
\hline Cryptocurrency & Model & Accuracy & Kappa & $95 \%$ Confidence Interval \\
\hline \multirow{9}{*}{$\mathrm{BCH}$} & NB & 52.91 & -0.0349 & $(0.4553,0.602)$ \\
\hline & $\mathrm{C} 5$ & 67.72 & 0.0000 & $(0.6056,0.7433)$ \\
\hline & BG & 59.26 & 0.0186 & $(0.5189,0.6633)$ \\
\hline & NBG & 99.47 & 0.9849 & $(0.9709,0.9999)$ \\
\hline & SVM & 67.72 & 0.0000 & $(0.6056,0.7433)$ \\
\hline & RF & 58.73 & -0.0147 & $(0.5136,0.6583)$ \\
\hline & MLR & 67.72 & 0.0000 & $(0.6056,0.7433)$ \\
\hline & RNN & 56.86 & 0.0486 & $(0.5359,0.6009)$ \\
\hline & LSTM & 59.91 & 0.0000 & $(0.5666,0.6310)$ \\
\hline \multirow[t]{9}{*}{$\mathrm{BCN}$} & NB & 66.67 & -0.0133 & $(0.5946,0.7334)$ \\
\hline & $\mathrm{C} 5$ & 68.78 & 0.0000 & $(0.6165,0.7531)$ \\
\hline & BG & 60.32 & -0.0088 & $(0.5296,0.6734)$ \\
\hline & NBG & 98.94 & 0.9568 & $(0.9623,0.9987)$ \\
\hline & SVM & 68.78 & 0.00 & $(0.6165,0.7531)$ \\
\hline & $\mathrm{RF}$ & 60.32 & -0.0421 & $(0.5296,0.6734)$ \\
\hline & MLR & 68.78 & 0.0000 & $(0.6165,0.7531)$ \\
\hline & RNN & 3.92 & 0.0024 & $(0.0276,0.0539)$ \\
\hline & LSTM & 65.80 & 0.0000 & $(0.6263,0.6886)$ \\
\hline \multirow[t]{9}{*}{ BSV } & NB & 62.96 & -0.0413 & $(0.5565,0.6986)$ \\
\hline & $\mathrm{C} 5$ & 70.37 & 0.0000 & $(0.6331,0.7678)$ \\
\hline & BG & 60.85 & -0.0015 & $(0.535,0.6785)$ \\
\hline & NBG & 99.76 & 0.9906 & $(0.9865,0.9999)$ \\
\hline & SVM & 70.37 & 0.00 & $(0.6331,0.7678)$ \\
\hline & RF & 64.55 & -0.0067 & $(0.5728,0.7136)$ \\
\hline & MLR & 70.37 & 0.0000 & $(0.6331,0.7678)$ \\
\hline & RNN & 100 & 1.0000 & $(0.9960,1.0000)$ \\
\hline & LSTM & 61.98 & 0.0000 & $(0.5875,0.6513)$ \\
\hline \multirow[t]{9}{*}{ BTC } & NB & 74.60 & 0.0299 & $(0.6778,0.8064)$ \\
\hline & $\mathrm{C} 5$ & 74.07 & 0.0000 & $(0.6721,0.8016)$ \\
\hline & $\mathrm{BG}$ & 60.85 & -0.0765 & $(0.535,0.6785)$ \\
\hline & NBG & 99.79 & 0.9916 & $(0.9886,0.9999)$ \\
\hline & SVM & 74.07 & 0.0000 & $(0.6721,0.8016)$ \\
\hline & $\mathrm{RF}$ & 64.02 & -0.08 & $(0.5674,0.7086)$ \\
\hline & MLR & 74.07 & 0.0000 & $(0.6721,0.8016)$ \\
\hline & RNN & 1.63 & 0.0030 & $(0.0092,0.0268)$ \\
\hline & LSTM & 68.3 & 0.0047 & $(0.6518,0.7130)$ \\
\hline \multirow[t]{9}{*}{$\mathrm{CCN}$} & NB & 44.97 & -0.0699 & $(0.3775,0.5236)$ \\
\hline & $\mathrm{C} 5$ & 74.60 & 0.0000 & $(0.6778,0.8064)$ \\
\hline & BG & 57.14 & 0.0348 & $(0.4976,0.643)$ \\
\hline & NBG & 98.94 & 0.9035 & $(0.9623,0.9987)$ \\
\hline & SVM & 74.60 & 0.00 & $(0.6778,0.8064)$ \\
\hline & RF & 60.85 & -0.0476 & $(0.5350,0.6785)$ \\
\hline & MLR & 74.60 & 0.0000 & $(0.6778,0.8064)$ \\
\hline & RNN & 68.30 & 0.0000 & $(0.6518,0.7130)$ \\
\hline & LSTM & 68.30 & 0.0000 & $(0.6518,0.7130)$ \\
\hline \multirow[t]{9}{*}{$\mathrm{CDO}$} & NB & 47.62 & 0.0000 & $(0.4032,0.5499)$ \\
\hline & $\mathrm{C} 5$ & 47.62 & 0.0000 & $(0.4032,0.5499)$ \\
\hline & BG & 52.38 & 0.0550 & $(0.4501,0.5968)$ \\
\hline & NBG & 100 & 1 & $(0.9807,1)$ \\
\hline & SVM & 47.62 & 0.0000 & $(0.4032,0.5499)$ \\
\hline & RF & 55.03 & 0.1106 & $(0.4764,0.6225)$ \\
\hline & MLR & 47.62 & 0.0000 & $(0.4032,0.5499)$ \\
\hline & RNN & 53.92 & -0.0440 & $(0.5063,0.5718)$ \\
\hline & LSTM & 54.14 & 0.0000 & $(0.5085,0.5740)$ \\
\hline \multirow[t]{9}{*}{ CLK } & NB & 26.98 & 0.0047 & $(0.208,0.3391)$ \\
\hline & $\mathrm{C} 5$ & 74.60 & 0.0000 & $(0.6778,0.8064)$ \\
\hline & BG & 65.61 & -0.0581 & $(0.5837,0.7235)$ \\
\hline & NBG & 91.53 & 0.5127 & $(0.8662,0.9508)$ \\
\hline & SVM & 74.60 & 0.00 & $(0.6778,0.8064)$ \\
\hline & RF & 70.90 & 0.041 & $(0.6387,0.7726)$ \\
\hline & MLR & 71.96 & -0.0503 & $(0.6498,0.7824)$ \\
\hline & RNN & 69.39 & 0.0000 & $(0.6630,0.7236)$ \\
\hline & LSTM & 69.39 & 0.0000 & $(0,6630,0.7236)$ \\
\hline \multirow[t]{9}{*}{ EOS } & NB & 68.78 & 0.0000 & $(0.6165,0.7531)$ \\
\hline & $\mathrm{C} 5$ & 68.78 & 0.0000 & $(0.6165,0.7531)$ \\
\hline & BG & 56.61 & 0.0299 & $(0.4923,0.6379)$ \\
\hline & NBG & 98.94 & 0.9554 & $(0.9623,0.9987)$ \\
\hline & SVM & 68.78 & 0.0000 & $(0.6165,0.7531)$ \\
\hline & $\mathrm{RF}$ & 54.5 & -0.0361 & $(0.4711,0.6174)$ \\
\hline & MLR & 68.78 & 0.0000 & $(0.6165,0.7531)$ \\
\hline & RNN & 65.58 & 0.0000 & $(0.6240,0.6865)$ \\
\hline & LSTM & 65.58 & 0.0000 & $(0.6240,0.6865)$ \\
\hline ETH & NB & 67.72 & 0.0000 & $(0.6001,0.7384)$ \\
\hline
\end{tabular}




\begin{tabular}{|c|c|c|c|c|}
\hline & $\mathrm{C} 5$ & 67.72 & 0.0000 & $(0.6001,0.7384)$ \\
\hline & $\mathrm{BG}$ & 58.73 & -0.0239 & $(0.5136,0.6583)$ \\
\hline & NBG & 88.36 & 0.5863 & $(0.8291,0.9256)$ \\
\hline & SVM & 67.20 & 0.0000 & $(0.6001,0.7384)$ \\
\hline & $\mathrm{RF}$ & 57.67 & -0.0216 & $(0.5029,0.6481)$ \\
\hline & MLR & 67.20 & 0.0000 & $(0.6001,0.7384)$ \\
\hline & RNN & 0.04 & 0.0000 & $(0.0012,0.0111)$ \\
\hline & LSTM & 65.25 & 0.0041 & $(0.6207,0.6833)$ \\
\hline \multirow[t]{9}{*}{ LTC } & NB & 67.20 & 0.0000 & $(0.6001,0.7384)$ \\
\hline & $\mathrm{C} 5$ & 67.20 & 0.0000 & $(0.6001,0.7384)$ \\
\hline & NB & 60.85 & 0.0286 & $(0.535,0.6785)$ \\
\hline & NBG & 100 & 1.0000 & $(0.9807,1.0000)$ \\
\hline & SVM & 67.20 & 0.000 & $(0.6001,0.7384)$ \\
\hline & $\mathrm{RF}$ & 61.90 & -0.0013 & $(0.5457,0.6886)$ \\
\hline & MLR & 67.20 & 0.0000 & $(0.6001,0.7384)$ \\
\hline & RNN & 15.47 & 0.0000 & $(0.1319,0.1797)$ \\
\hline & LSTM & 62.64 & 0.0014 & $(0.5942,0.6578)$ \\
\hline \multirow[t]{9}{*}{ MNO } & NB & 68.25 & 0.0000 & $(0.611,0.7482)$ \\
\hline & $\mathrm{C} 5$ & 68.25 & 0.0000 & $(0.611,0.7482)$ \\
\hline & NB & 62.96 & 0.0585 & $(0.5565,0.6986)$ \\
\hline & NBG & 100 & 1.0000 & $(0.9807,1.0000)$ \\
\hline & SVM & 68.25 & 0.0000 & $(0.6110,0.7482)$ \\
\hline & $\mathrm{RF}$ & 65.08 & 0.0883 & $(0.5782,0.7185)$ \\
\hline & MLR & 68.25 & 0.0000 & $(0.6110,0.7482)$ \\
\hline & RNN & 8.39 & 0.0000 & $(0.0683,0.1037)$ \\
\hline & LSTM & 64.38 & 0.0000 & $(0.6118,0.6748)$ \\
\hline \multirow[t]{9}{*}{ SLR } & NB & 71.43 & 0.0000 & $(0.6442,0.7775)$ \\
\hline & $\mathrm{C} 5$ & 71.43 & 0.0000 & $(0.6442,0.7775)$ \\
\hline & NB & 60.32 & -0.1006 & $(0.5296,0.6734)$ \\
\hline & NBG & 100 & 1.0000 & $(0.9807,1.0000)$ \\
\hline & SVM & 71.43 & 0.000 & $(0.6442,0.7775)$ \\
\hline & $\mathrm{RF}$ & 62.43 & -0.029 & $(0.5511,0.6936)$ \\
\hline & MLR & 71.43 & 0.0000 & $(0.6442,0.7775)$ \\
\hline & RNN & 68.85 & 0.0000 & $(0.6574,0.7183)$ \\
\hline & LSTM & 68.85 & 0.0000 & $(0.6574,0.7183)$ \\
\hline \multirow[t]{9}{*}{ TTR } & NB & 75.66 & 0.0000 & $(0.689,0.816)$ \\
\hline & $\mathrm{C} 5$ & 75.66 & 0.0000 & $(0.689,0.816)$ \\
\hline & NB & 64.02 & -0.1075 & $(0.5674,0.7086)$ \\
\hline & NBG & 100 & 1.0000 & $(0.9807,1.0000)$ \\
\hline & SVM & 75.66 & 0.0000 & $(0.6890,0.8160)$ \\
\hline & RF & 66.67 & -0.0348 & $(0.5946,0.7334)$ \\
\hline & MLR & 75.66 & 0.0000 & $(0.689,0.8160)$ \\
\hline & RNN & 67.65 & 0.0045 & $(0.6451,0.7067)$ \\
\hline & LSTM & 67.54 & 0.0000 & $(0.6440,0.7056)$ \\
\hline \multirow[t]{9}{*}{$\mathrm{TZS}$} & NB & 76.19 & 0.0000 & $(0.6947,0.8207)$ \\
\hline & $\mathrm{C} 5$ & 76.19 & 0.0000 & $(0.6947,0.8207)$ \\
\hline & $\mathrm{NB}$ & 60.32 & -0.0855 & $(0.5296,0.6734)$ \\
\hline & NBG & 100 & 1.0000 & $(0.9807,1.0000)$ \\
\hline & SVM & 76.19 & 0.0000 & $(0.6947,0.8207)$ \\
\hline & $\mathrm{RF}$ & 66.14 & -0.0630 & $(0.5891,0.7285)$ \\
\hline & MLR & 76.72 & 0.0335 & $(0.7004,0.8255)$ \\
\hline & RNN & 71.46 & 0.0000 & $(0.6842,0.7436)$ \\
\hline & LSTM & 71.46 & 0.0000 & $(0.6842,0.7436)$ \\
\hline \multirow[t]{9}{*}{ XRP } & NB & 68.25 & 0.0000 & $(0.611,0.7482)$ \\
\hline & $\mathrm{C} 5$ & 68.25 & 0.0000 & $(0.611,0.7482)$ \\
\hline & NB & 61.90 & -0.0471 & $(0.5457,0.6886)$ \\
\hline & NBG & 100 & 1.0000 & $(0.9807,1.0000)$ \\
\hline & SVM & 68.25 & 0.0000 & $(0.6110,0.7482)$ \\
\hline & $\mathrm{RF}$ & 63.49 & -0.0380 & $(0.5619,0.7036)$ \\
\hline & MLR & 68.25 & 0.0000 & $(0.6110,0.7482)$ \\
\hline & RNN & 65.14 & 0.0000 & $(0.6196,0.6823)$ \\
\hline & LSTM & 65.14 & 0.0000 & $(0.6196,0.6823)$ \\
\hline
\end{tabular}

